\title{
36. CENOZOIC CALCAREOUS NANNOFOSSIL BIOSTRATIGRAPHY ON THE EXMOUTH PLATEAU, EASTERN INDIAN OCEAN ${ }^{1}$
}

\author{
William G. Siesser ${ }^{2}$ and Timothy J. Bralower ${ }^{3}$
}

\begin{abstract}
Six sites (759-764) were drilled on the Exmouth Plateau during Ocean Drilling Program Leg 122. Nannofossilrich Cenozoic sediments were recovered at all six sites, reflecting the open-ocean conditions that prevailed over the Exmouth Plateau during the Cenozoic. Calcareous nannofossils are abundant, diverse ( 250 different species identified), and generally well preserved throughout the composite lower Paleocene to Quaternary section. The diversity and preservation of nannofossils permits a high degree of stratigraphic resolution at each site. Site 762 on the central part of the Exmouth Plateau contains an almost unbroken Cenozoic record (only Miocene Zones NN3, NN8, and NN10 are missing). This site may prove to be a useful Cenozoic biostratigraphic and biomagnetochronologic reference section for the eastern Indian Ocean.
\end{abstract}

\section{INTRODUCTION}

The Exmouth Plateau is a rifted and subsided fragment of continental crust lying off the coast of northwestern Australia (Fig. 1). The relatively thin cover of post-rift sediments over this plateau makes it an ideal location for study of the evolution of the plateau by drilling through the overburden to pre-rift rocks. The Exmouth Plateau has, moreover, consistently remained elevated above the calcite compensation depth during its post-rift history, a circumstance favorable for preservation of the carbonate record.

Six sites (759-764) were drilled on the Exmouth Plateau during Leg 122 of the Ocean Drilling Program (ODP). Two of the sites (762 and 763) are located on the central Exmouth Plateau; the remaining four are on a northern marginal horst named the Wombat Plateau (Fig. 1). Sedimentology, lithostratigraphy, and other details of these sites are described in detail in the Leg 122 Initial Reports (Haq, von Rad, O'Connell, et al., 1990).

Results of the Exmouth Plateau drilling have provided a much clearer understanding of the evolutionary development of this part of the Indian Ocean from the time of initial rifting (Triassic), through breakup and separation (Late JurassicNeocomian) and the development of a juvenile ocean (AptianConiacian), to the establishment of mature ocean conditions (post-Coniacian).

Integrated geologic studies on the plateau rely on a refined stratigraphic framework for placing events in an accurate chronostratigraphic context. The purpose of this paper is to document the biostratigraphy of the major portion of the mature ocean phase, the Cenozoic, using calcareous nannofossils.

\section{BIOSTRATIGRAPHY}

Smear slides of core samples were examined using a light microscope. The appendix lists the calcareous nannofossil

\footnotetext{
1 von Rad, U., Haq, B. U., et al., 1992. Proc. ODP, Sci. Results, 122: College Station, TX (Ocean Drilling Program).

2 Department of Geology, Vanderbilt University, Nashville, TN 37235 , U.S.A.

${ }^{3}$ Department of Geology, Florida International University, Miami, FL 33199, U.S.A. (Current address: Department of Geology, University of North Carolina, Chapel Hill, NC 27599, U.S.A.)
}

species found in the Cenozoic sediments on the Exmouth and Wombat plateaus.

Nannofossils are abundant in almost all Cenozoic samples examined and preservation ranges from moderately well preserved to very well preserved. Where range charts are given in the following sections, the relative abundances of individual species are indicated as follows: $\mathrm{A}=$ abundant, more than 10 specimens of a single species per field of view at a magnification of $1000 \times ; C=$ common, 1 to 10 specimens per field of view; $F=$ few, one specimen per $2-10$ fields; $R=$ rare, one specimen per 11-100 fields; and V = very rare, one specimen per 101-1000 fields (Tables 1-5).

Selected species (mostly those used in the biomagnetochronologic assessment) are illustrated in Plates 1-5. Smear slides and photographic negatives of these species are stored in the Micropaleontology Collection, Department of Geology, Vanderbilt University.

\section{TAXONOMIC NOTES}

The following notes on taxa are arranged in the general order the taxa are encountered in the cores, from oldest to youngest.

Prinsius spp. A number of small (2-6 $\mu \mathrm{m})$ species of Prinsius occur in Zones NP1 and NP2. Perch-Nielsen (1985) has recognized $P$. petalosus, $P$. dimorphosus, $P$. tenuiculum, $P$. africanus, and $P$. martinii. These small forms could not be resolved with consistency using the light microscope, so all have been included in the range-chart tables under the category "small Prinsius spp." P. bisulcus is a larger $(>6 \mu \mathrm{m})$, distinctive form, which is listed separately in the tables.

Zygodiscus bramlettei/Z. herlynii. The distinction between these two species is based on the relative thickness of the coccolith wall and the relative size of the central openings. We found it difficult to make confident assignments to one species or the other, and have elected to combine the two forms into a single category in the range charts.

Ericsonia cava and Coccolithus pelagicus. Where both species occur together in the Paleocene, we have used E. cava for elliptical forms with a distinctive open central area that is usually about one-third the total width of the specimen. $C$. pelagicus looks somewhat similar at the start of its range, but has a smaller central opening, or contains a structural element in the central opening.

Dictyococcites callidus and Dictyococcites daviesii. We could not differentiate these two species using the light 


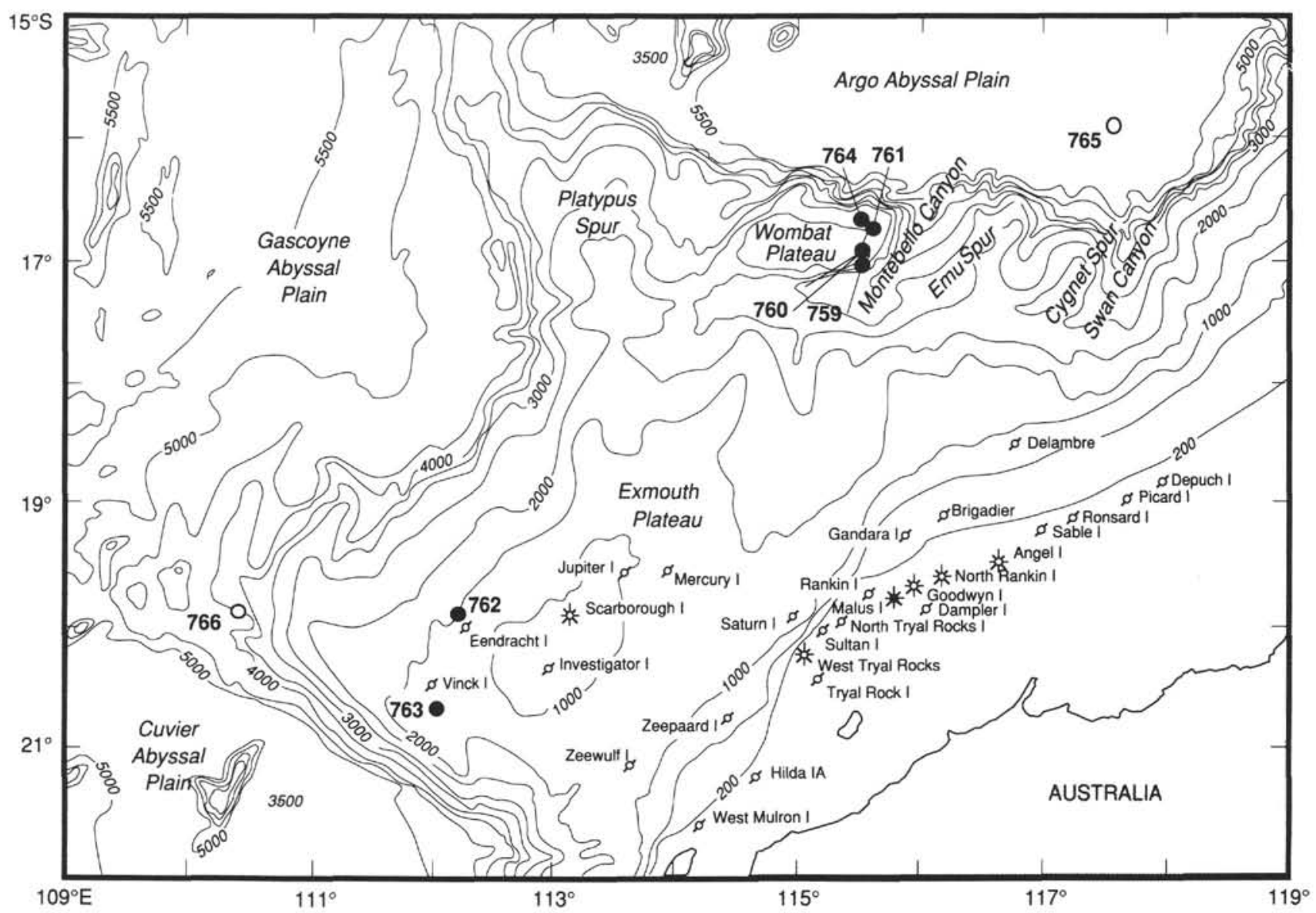

Figure 1. Location map showing Leg 122 drill sites on the central Exmouth Plateau (Sites 762 and 763) and on the Wombat Plateau (Sites 759, 760, 761, and 764). Contours are in meters below sea level. Map is from Haq et al. (1988).

microscope; they are accordingly listed together under $D$. callidus s.1.

Blackites spinosus/B. tenuis. The majority of specimens of these species are found as tapering spines with the heads missing (only an occasional specimen is complete and can be definitely assigned to either B. spinosus or B. tenuis). All specimens are therefore listed as Blackites spinosus/B. tenuis on the range charts.
Chiasmolithus altus. We found some variation in the shape of the central cross in this species in Zones NP22 and NP23. Some specimens have bars that meet at $90^{\circ}$ angles (C. altus s.s.), but others have a slight curvature of one bar (see Pl. 1, Fig. 4). We believe this is merely intraspecific variation and have recorded both types under $C$. altus s.I. in the range charts.

Discoaster variabilis. Considerable variation exists in the size and angle of ray bifurcations of this species (thus the

Table 1. Calcareous nannofossils in Hole 760A.

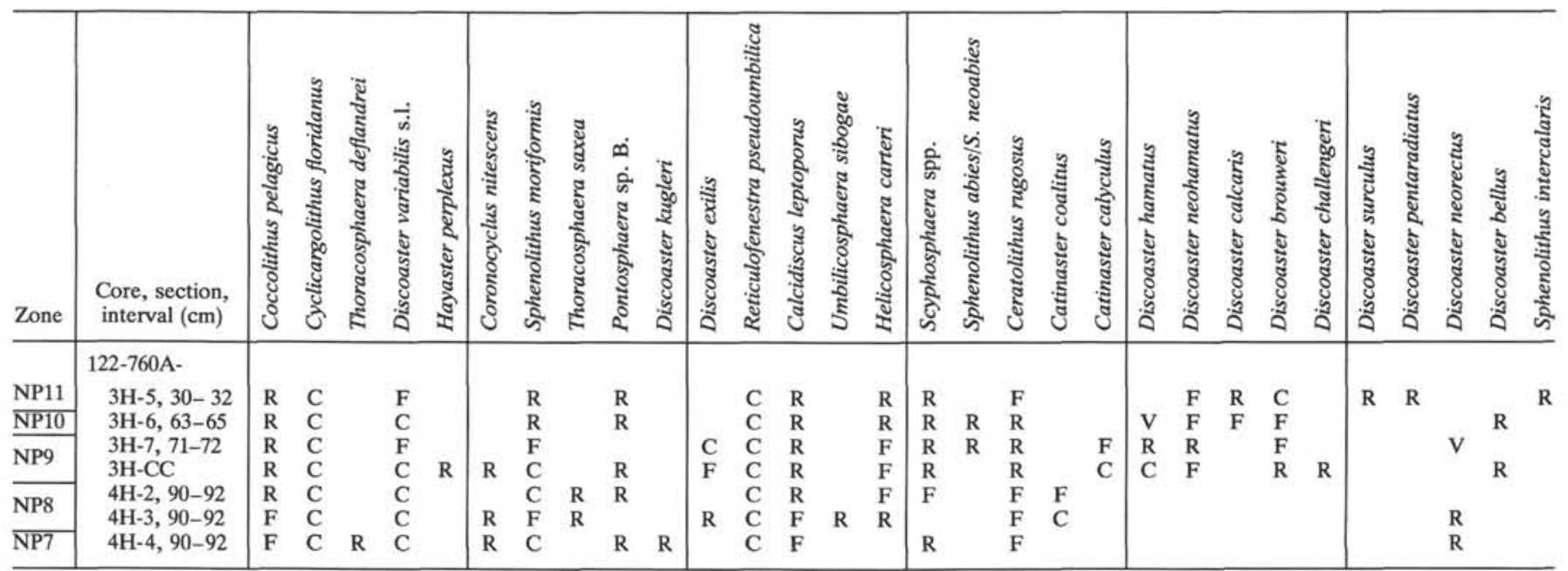


Table 2. Calcareous nannofossils in Hole 761B.

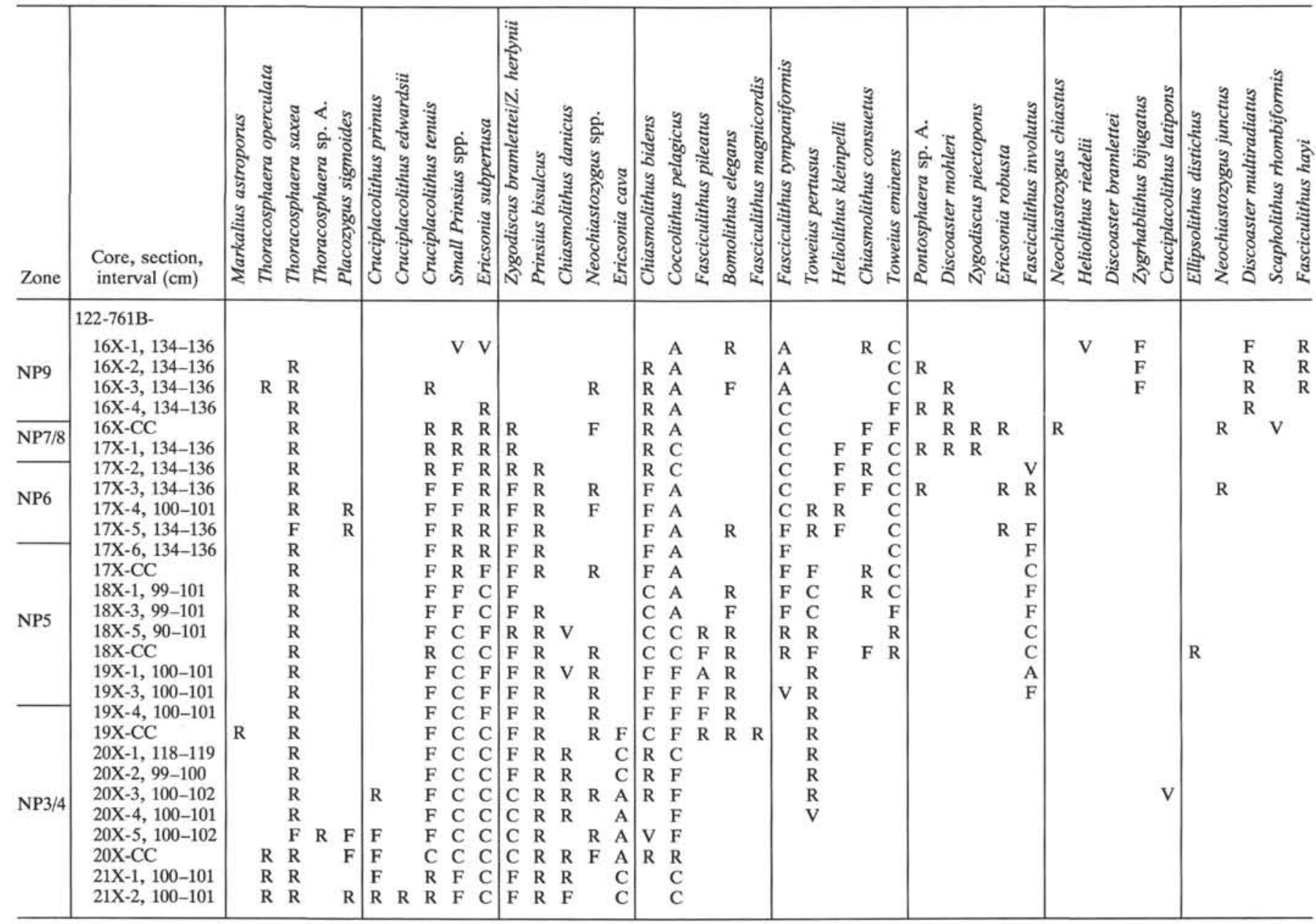

Table 2 (continued).

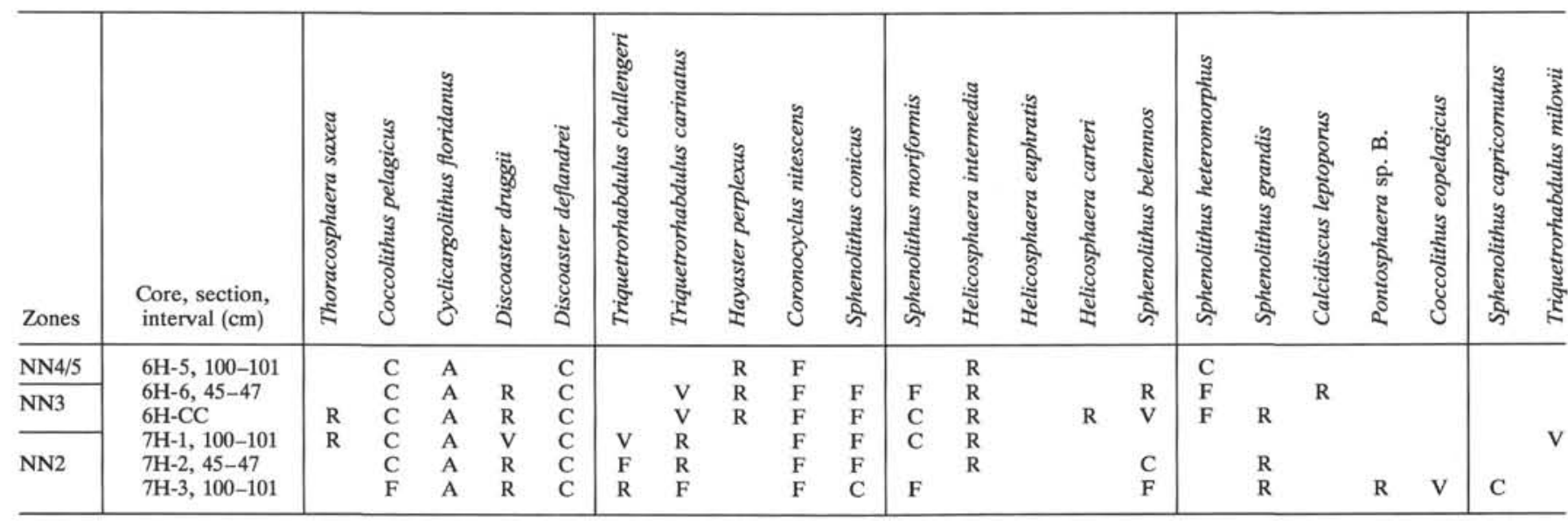

species epithet). Bifurcations range from relatively small and narrow-angled to large, broadly bifurcate tips (e.g., Pl. 5, Fig. 12). The broad-tipped forms have been named $D$. variabilis pansus by Bukry and Percival (1971) and $D$. pansus by Bukry (1973). Discoaster variabilis s.s. and D. pansus appear to grade into one another in our samples, and we have therefore elected to list both end members and intermediate forms under D. variabilis s.l. in the range charts.
Rhabdosphaera procera. This species is distinguished from $R$. claviger by the parallel sides of the spine of the former taxon. $R$. procera is small at the beginning of its range but becomes larger than $R$. claviger in the Pleistocene.

Sphenolithus abies/S. neoabies. We found it difficult to distinguish these two small species consistently and so have combined them where they occur together in the late Miocene interval. 
Table 3. Calcareous nannofossils in Hole 762B.

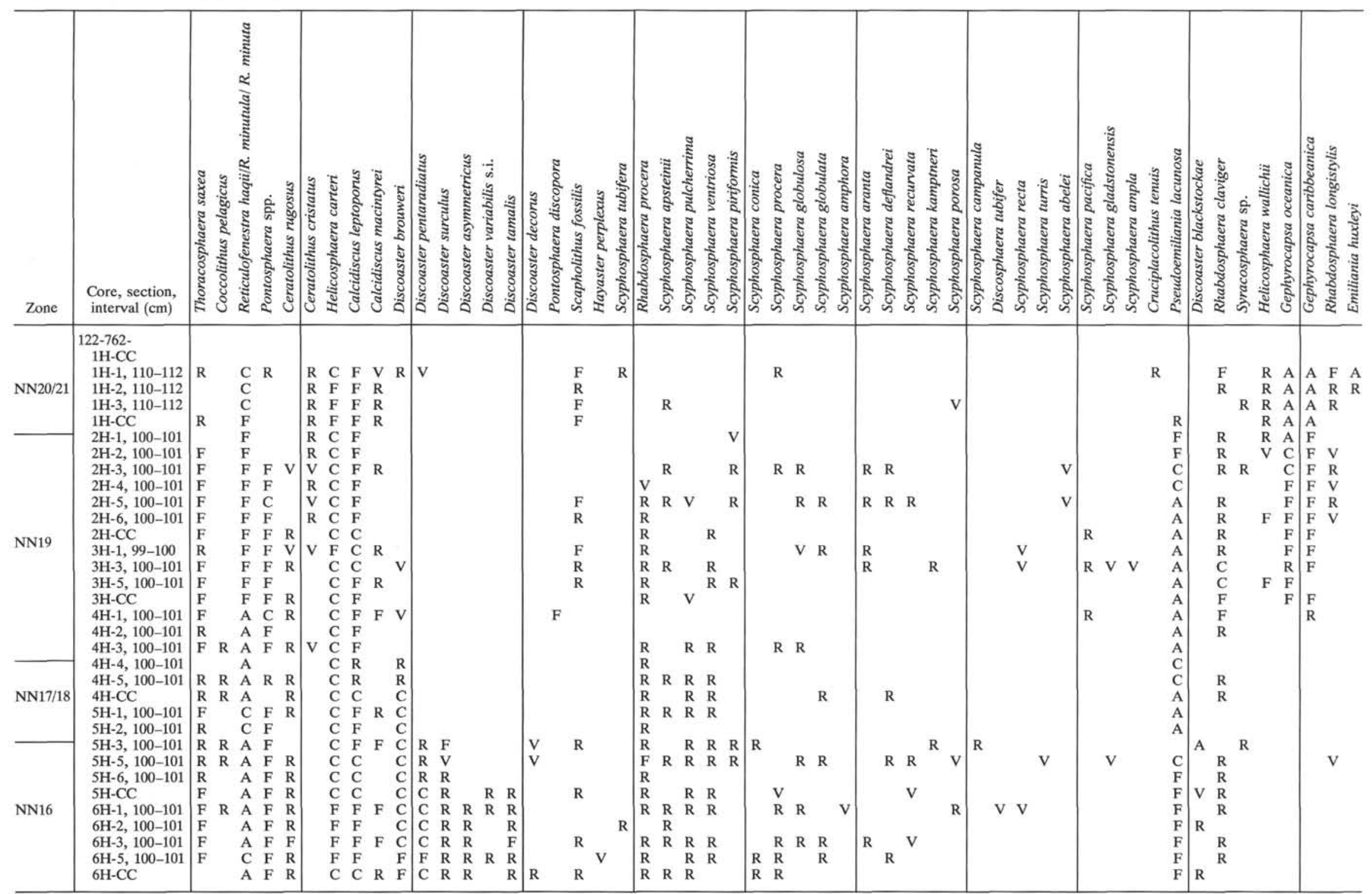


Table 3 (continued).

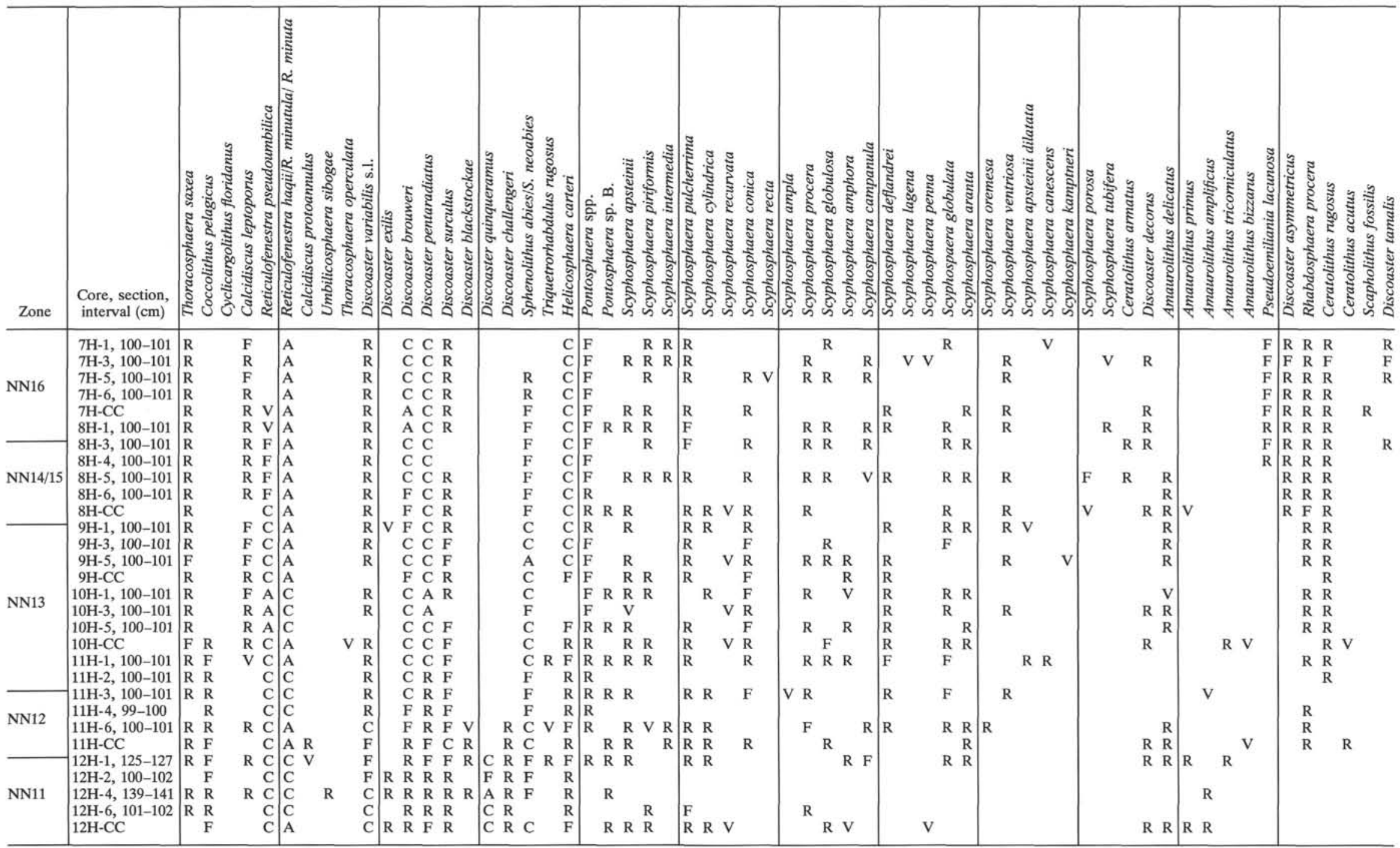


Table 3 (continued).

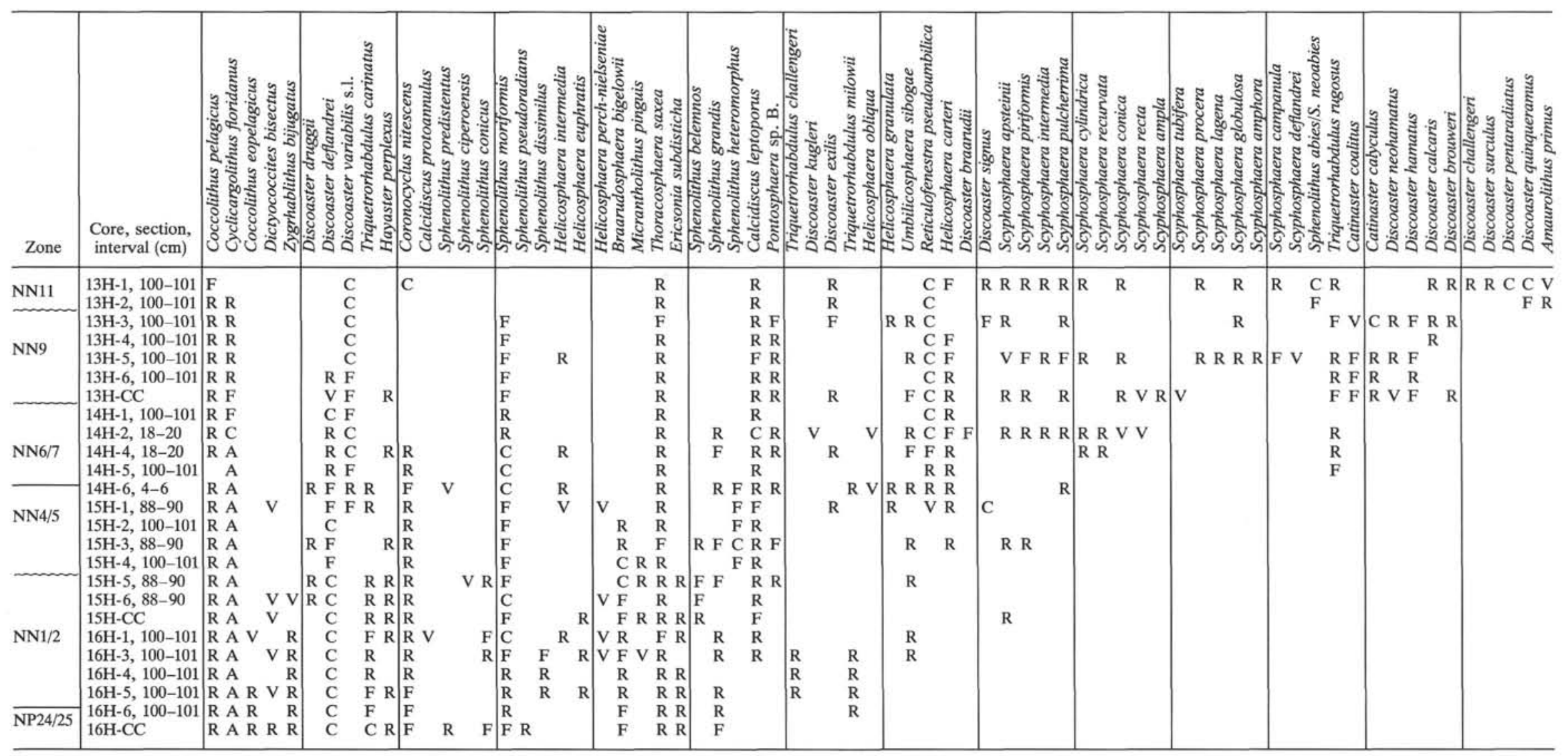


Table 3 (continued).

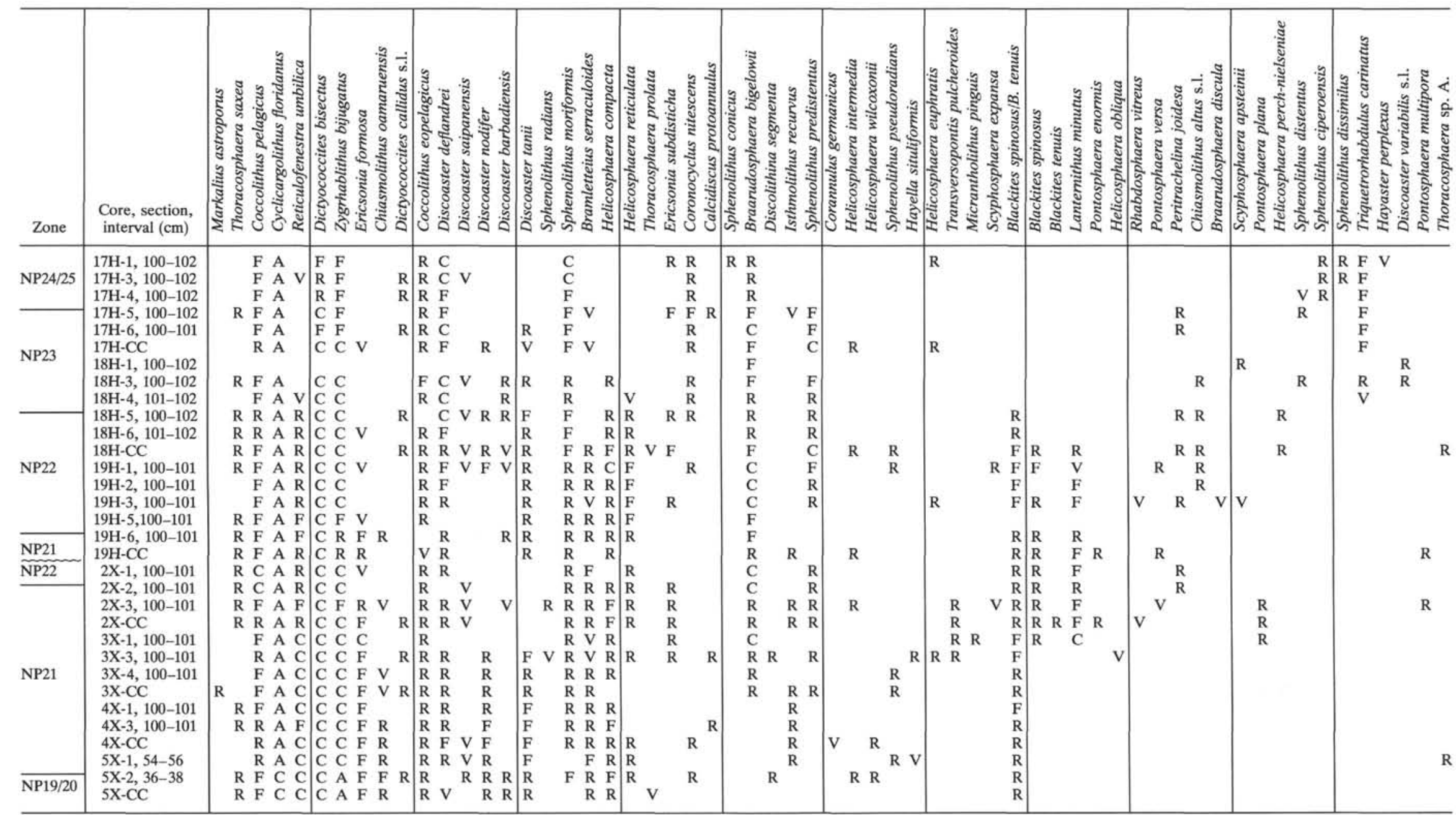


Table 4. Calcareous nannofossils in Hole $762 \mathrm{C}$.

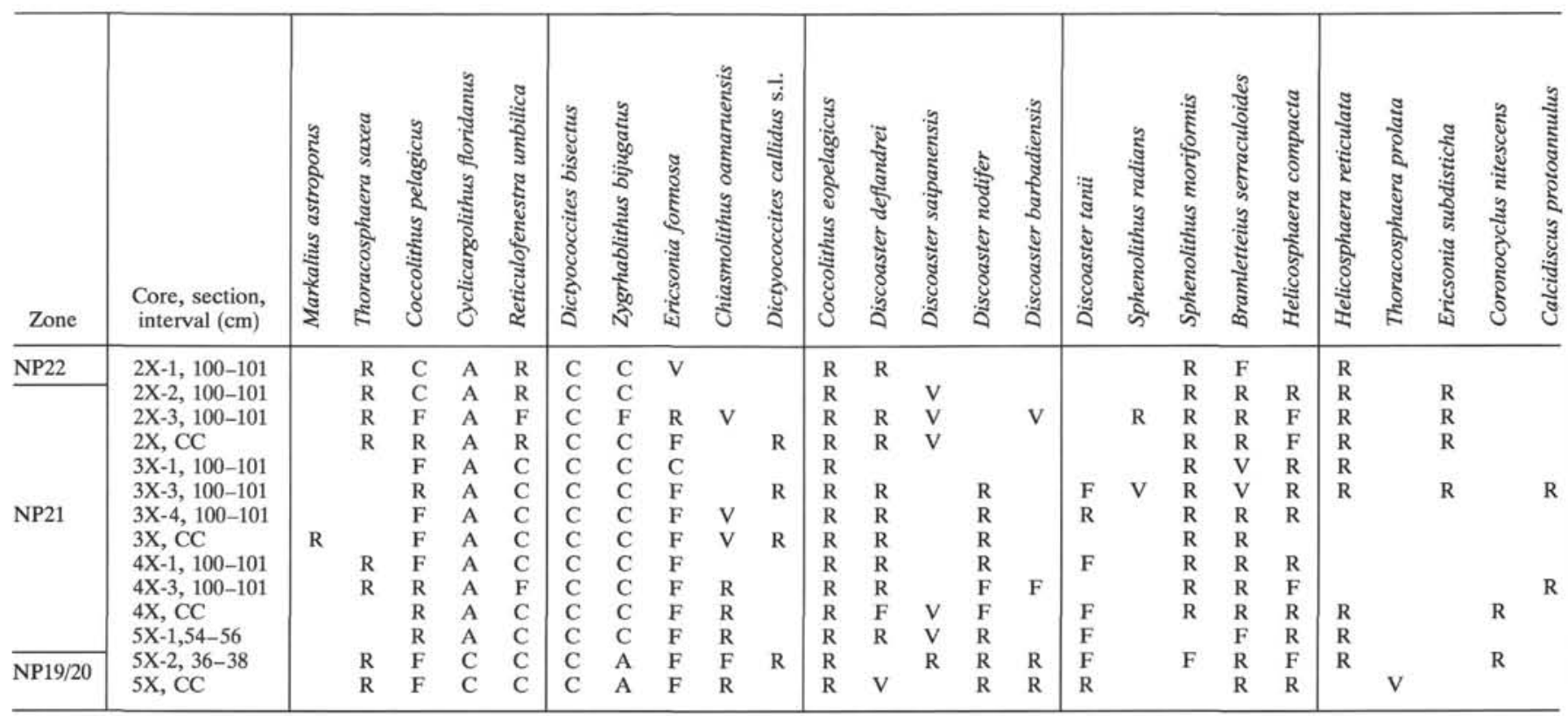

Reticulofenestra haqii/R. minuta/R. minutula. These three small species are also difficult to separate, so we have also listed them under a single category.

Thoracospheara sp. A. This species resembles T. saxea but has smaller crystal elements making up the test.

Pontosphaera sp. A. This is a large $(10-15 \mu \mathrm{m})$, elliptical form that appears bright white between crossed nicols.

Pontosphaera sp. B. This large $(8-12 \mu \mathrm{m})$, thick form shows bright multicolors between crossed nicols.

\section{ZONATION}

Although we used Martini's (1971) biostratigraphic zonation in this study, some modifications to the standard scheme were necessary, owing to the rarity or absence of several marker species. The following paragraphs describe the zonational conventions we used and add some relevant stratigraphic comments.

Evolutionary first appearances are more sharply defined than extinctions, largely because upward reworking blurs true extinction horizons. In Tables 1-5, if the first occurrence of a zonal marker species was designated as "very rare," that level was still considered to be the evolutionary first occurrence and the zonal boundary was drawn below that level. If the last occurrence was "very rare," however, the boundary was usually drawn just below that level, especially if the relative abundance had dropped from "few" or "rare" (but consistently "rare") down to "very rare," then "absent." A few "very rare" to "rare" specimens are expected to be reworked above any extinction level.

Zone NP1-NP2 boundary. We used the first appearance of Cruciplacolithus primus to mark this boundary in our study. Romein (1979) described $C$. edwardsii as a form that evolved from $C$. primus, and which first appears somewhat later than C. primus. In Hole $762 \mathrm{C}$, however, both species make their first appearance in the same sample, although with $C$. primus being much more common than $C$. edwardsii (Table 4). Cruciplacolithus tenuis s.s. first appears slightly above $C$. primus and $C$. edwardsii at Site 762.

Zone NP2-NP3/NP4 boundary. NP3 and NP4 are often combined, because Ellipsolithus macellus is almost always a rare form. The NP2-NP3/NP4 boundary is drawn at the level of the first appearance of definite Chiasmolithus danicus at Site 762. The zonal boundary drawn on Table 4 and Figure 4 is considered tentative, and could be slightly lower, because C. danicus is not always readily distinguishable from Cruciplacolithus edwardsii.

Zone NP3/4-NP4 boundary. An approximate lower boundary for NP4 is drawn based on the first appearance of the secondary marker species Chiasmolithus bidens, whose first occurrence is considered to be in NP4 (Romein, 1979; PerchNielsen, 1985).

Zone NP7/NP8. Zones NP7 and NP8 are combined because Heliolithus riedelii, whose first occurrence defines the NP7-NP8 boundary, is too rare to be useful in these cores.

Zone NP15-NP16 boundary. The taxon defining this boundary (Rhabdosphaera gladius) is absent here. We have therefore used the last occurrence of Nannotetrina spp. and the first occurrence of Discoaster nodifer to approximate the boundary (see Perch-Nielsen, 1985).

Zone NP16-NP17 boundary. The last occurrence of the marker species Chiasmolithus solitus is not reliable here owing to its rarity. We have used the last occurrences of Reticulofenestra reticulata (just below the boundary) and Helicosphaera compacta (just above the boundary) to approximate the true zonal boundary (Perch-Nielsen, 1985).

Zone NP19/NP20. These zones are combined because the marker species (Sphenolithus pseudoradians) that divides the zones is rare here; furthermore, the range of this species is now considered to be diachronous (Perch-Nielsen, 1985).

Zone NP24/NP25. Zones NP24 and NP25 are combined because the boundary marker, Sphenolithus distentus, is too rare to be reliable in these cores.

Zone NP24/NP25-NN1/NN2 boundary. The unreliability of the range of Helicosphaera recta, which is the official marker of the NP25-NN1 boundary, is well known (PerchNielsen, 1985). The boundary here is approximated by the last occurrence of Dictyococcites bisecta (Perch-Nielsen, 1985).

Zone NN1/NN2. These zones are combined because Discoaster druggii is rare and difficult to distinguish consistently when any calcitic overgrowth obscures the ray points. 


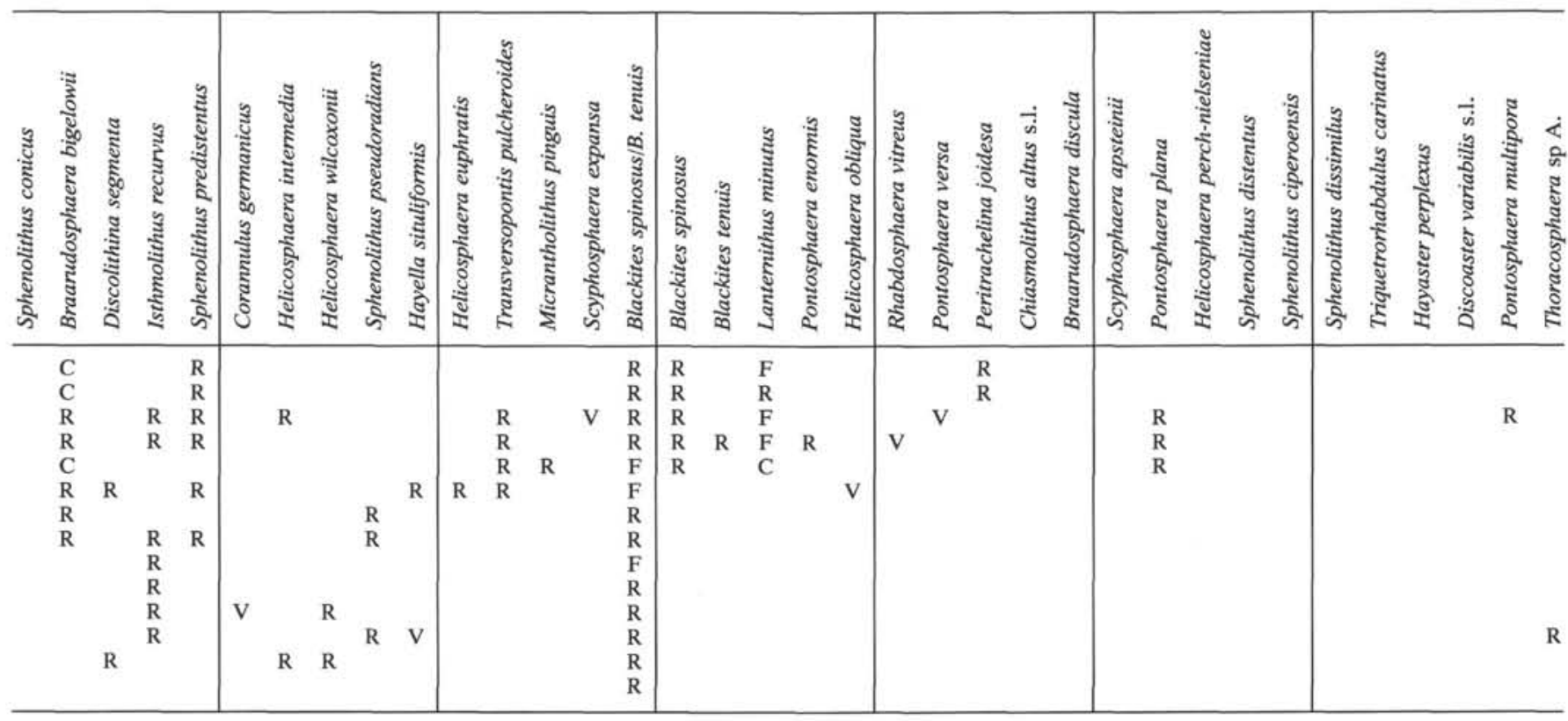

Zone NN4/NN5. These zones are combined because of the absence of the NN4-NN5 boundary marker, Helicosphaera ampliaperta.

Zone NN6/NN7. These zones are combined because the boundary marker, Discoaster kugleri, is rare and occurs sporadically.

Zone NN14/NN15. These zones are combined because the boundary marker, Amaurolithus tricorniculatus, is too rare to be reliable.
Zone NN17/NN18. Zone NN17 is an exceptionally thin zone; the extinction of Discoaster surculus (base of NN17) occurs only slightly before the extinction of $D$. pentaradiatus (top of NN17) (Perch-Nielsen, 1985). We could not separate the extinction levels of these two species here, so the two zones are therefore combined.

Zone NN20/NN21. These zones are combined in this light microscope study because the first appearance of Emiliania

Table 4 (continued).

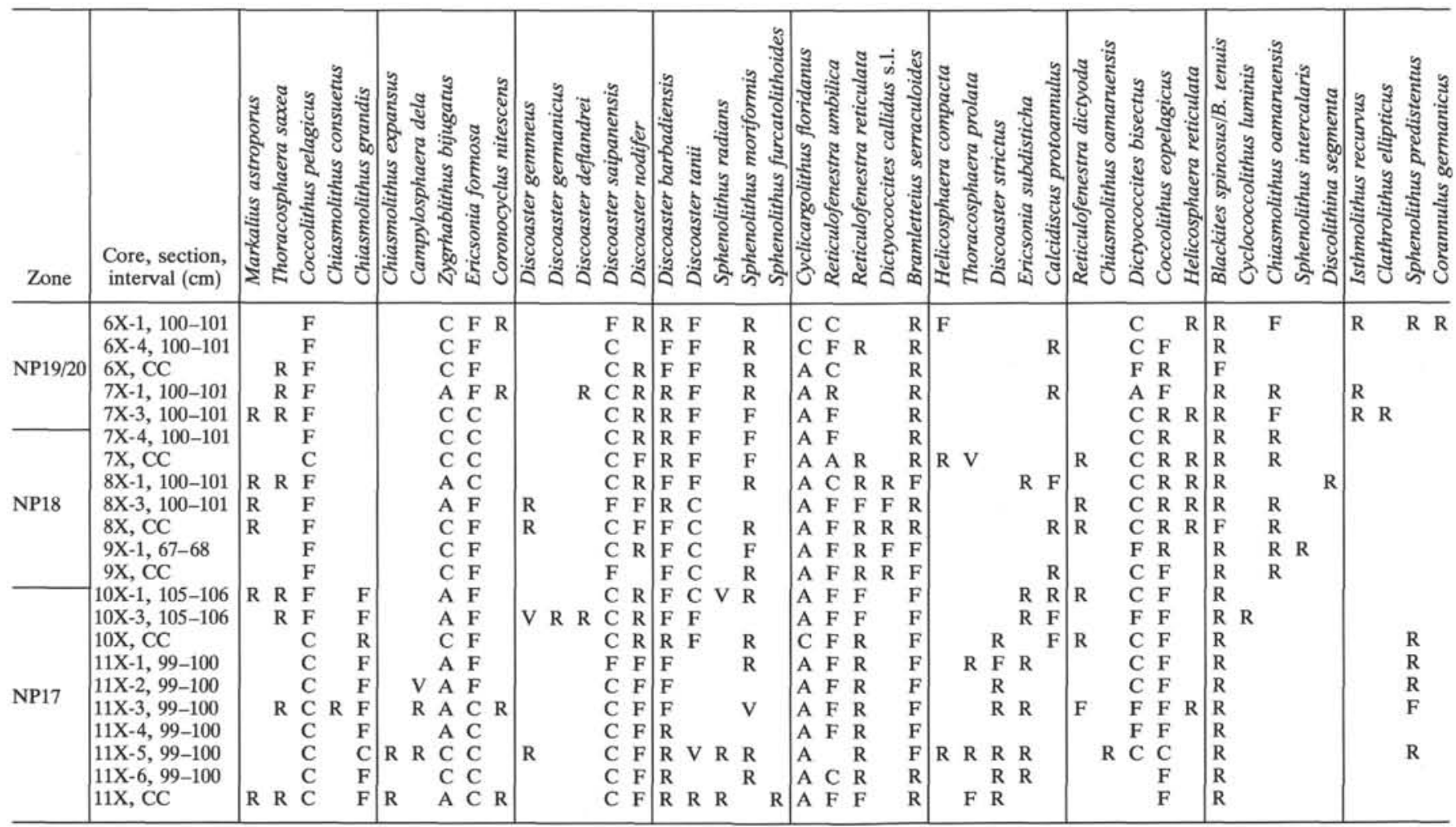


Table 4 (continued).

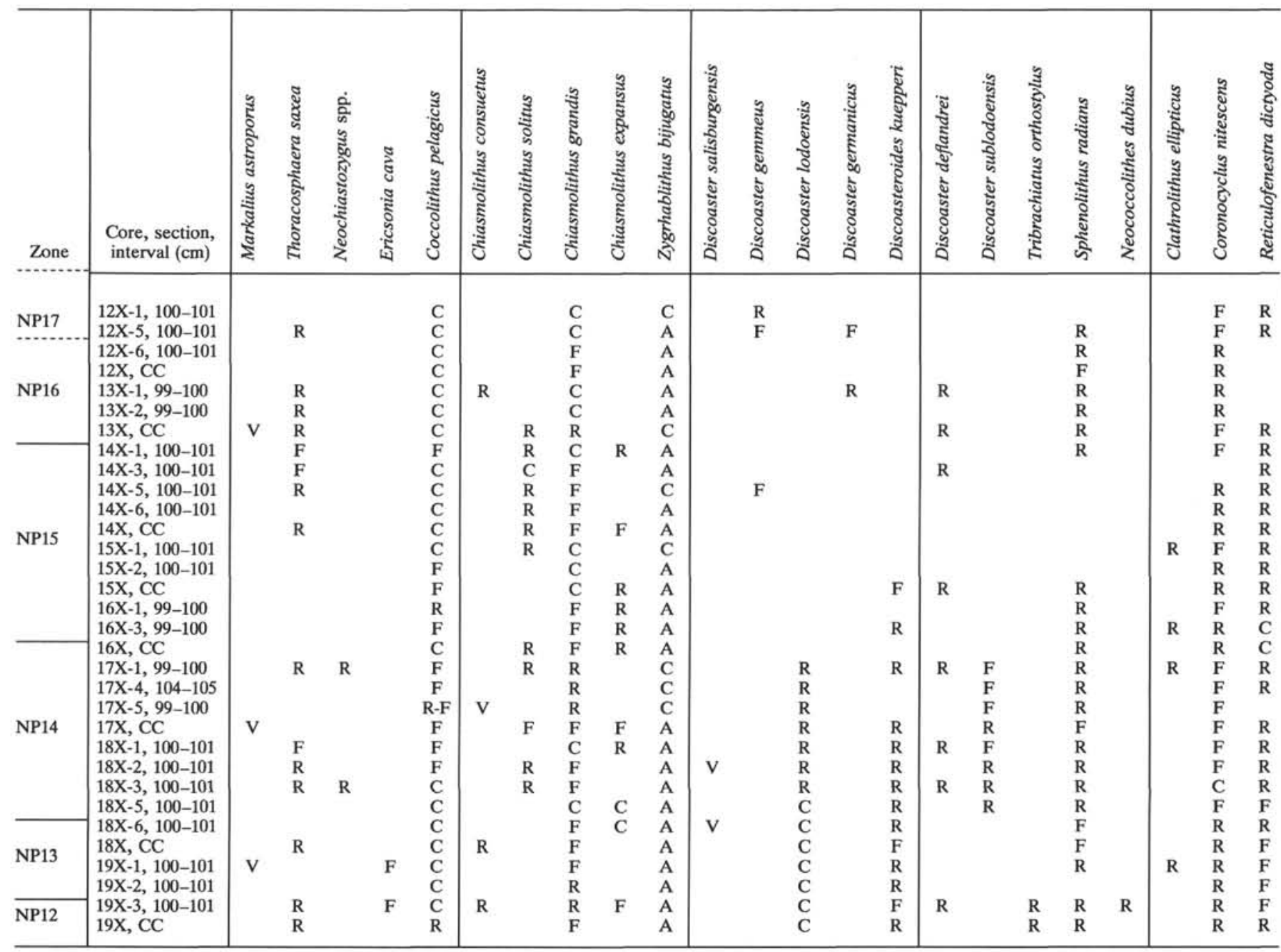

huxleyi can only be determined accurately using the electron microscope.

Figures 2 to 7 show the biostratigraphic zonation (Martini, 1971) for individual sites. Species used for recognizing each zonal boundary are described in detail in Haq, von Rad, O'Connell, et al. (1990) and will not be repeated here. Remarks on the biostratigraphy of each site are given in the following paragraphs. Site 762 may be considered an important reference section for the eastern Indian Ocean because of its stratigraphic continuity. The nannofossil assemblage at Site 762 is therefore described in considerably greater detail than the other sites.

\section{Site 759}

Two holes were drilled at this site: $759 \mathrm{~A}$ and $759 \mathrm{~B}$ (16 $57.24-.25^{\prime} \mathrm{S}, 115^{\circ} 33.61-.63^{\prime} \mathrm{E} ; 2092 \mathrm{~m}$ water depth). There was no core recovery at Hole 759A. Hole 759B was rotarycored to a depth of 308 meters below sea floor (mbsf), penetrating $40.5 \mathrm{~m}$ of Cenozoic sediments.

The interval from the top of Core 122-759B-3R to Section $122-759 \mathrm{~B}-4 \mathrm{R}-4,25 \mathrm{~cm}$, is Quaternary in age (Zones NN19NN21). A hiatus exists at this level, with the underlying sediments from Sections 122-759B-4R-4, $26 \mathrm{~cm}$, through 122-759B-5R-CC assignable to lower Miocene Zones NN4/ NN5. Core 122-759B-5R rests unconformably on Triassic rocks.

\section{Site 760}

Two holes were drilled at Site 760: 760A and 760B $\left(16^{\circ} 55.32^{\prime} \mathrm{S}, 115^{\circ} 32.48^{\prime} \mathrm{E} ; 1970 \mathrm{~m}\right.$ water depth). Hole $760 \mathrm{~A}$ was cored using the advanced piston corer (APC) to a depth of 83.7 mbsf (the base of the Tertiary), then continued to a depth of 284.9 mbsf using the extended core barrel (XCB).

Figure 2 shows the zonation of Cenozoic sediments in Hole $760 \mathrm{~A}$. The sequence ranges from upper Pleistocene (NN20/ NN21) to lower Eocene (NP10/NP11). Several hiatuses occur as shown by the missing zonal intervals NP21-NP22 (uppermost Eocene-lower Oligocene), NN4 (lower Miocene), NN12-NN15 (upper Miocene-lower Pliocene), and NN17NN18 (upper Pliocene). Zones NN8 and NN10 are missing at our almost complete "standard" Cenozoic Site 762, but are present here in Hole $760 \mathrm{~A}$; Table 1 is a checklist of species occurring across this interval.

\section{Site 761}

Three holes were drilled at this site: 761A, 761B, and 761C $\left(16^{\circ} 44.22-.26^{\prime} \mathrm{S}, 115^{\circ} 32.09-.10^{\prime} \mathrm{E} ; 2168 \mathrm{~m}\right.$ water depth). Only one core (Quaternary) was taken at Hole 761A. Hole 761B was APC-cored to a depth of 89.7 mbsf (middle Eocene), then XCB-cored to a depth of 286.7 mbsf (Triassic); the Cretaceous/Tertiary $(\mathrm{K} / \mathrm{T})$ boundary was encountered at 175.7 mbsf. Hole 761C was rotary-cored and two additional cores 
Table 4 (continued).

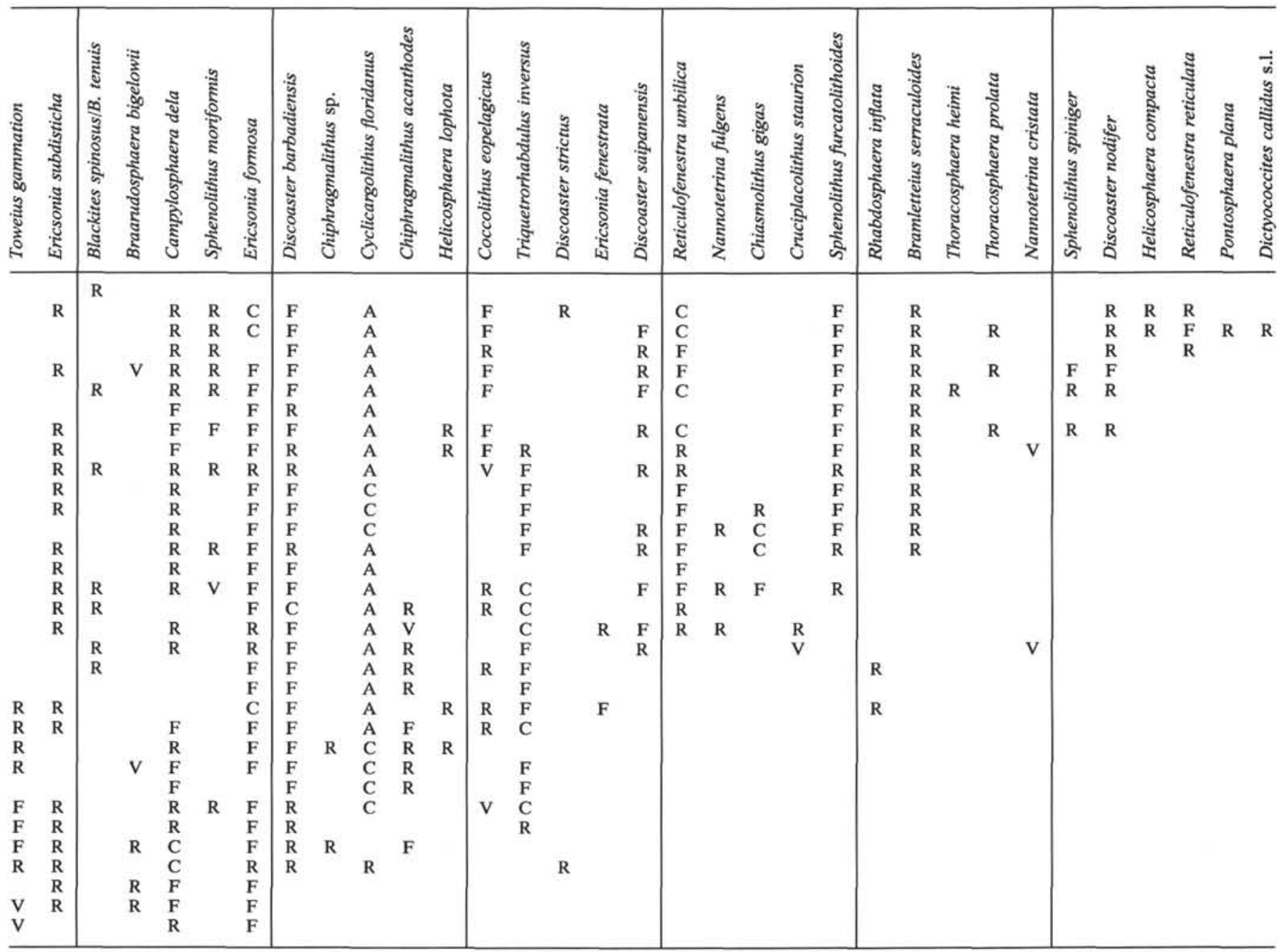

(122-761C-2R and $-3 R$ ) were taken across the $\mathrm{K} / \mathrm{T}$ boundary in this hole.

The Cenozoic sequence at Hole $761 \mathrm{~B}$ has a number of missing intervals. Hiatuses occur at the K/T boundary (NP1), in the lower Eocene (NP10-NP13), from the middle Eocene to the upper Oligocene (NP17-NP24), in the upper Miocene to lower Pliocene (NN9 (in part) to NN10 and NN12 to NN15), and in the upper Pliocene (NN17 to NN18) (Fig. 3). Hole 761C recovered a thin NP1 zonal interval, which is missing at Hole $761 \mathrm{~B}$.

The Paleocene at this site contains an assemblage of radiolarians suitable for establishing a Paleocene radiolarian zonation (Blome, this volume). This was an important discovery, since the Paleocene is currently unzoned by radiolarians. We have included a calcareous nannofossil range chart for the important Paleocene interval (Table 2), which also provides complementary data for the radiolarian zonation. We also include a range chart (Table 2) for the upper part of the lower Miocene (Zones NN2-NN4/NN5), since Zone NN3 is missing in our standard section at Site 762 .

\section{Site 762}

Three holes were drilled at Site 762: 762A, 762B, and 762C (19 53.23-.24'S, $112^{\circ} 15.24-.26^{\prime} \mathrm{E} ; 1360 \mathrm{~m}$ water depth). At Hole $762 \mathrm{~A}$, a single core of Quaternary age was recovered. Hole 762B was APC-cored to a depth of 175.4 mbsf (lower
Oligocene). Hole $762 \mathrm{C}$ was XCB-cored to a depth of $940 \mathrm{mbsf}$ (Lower Cretaceous). The $\mathrm{K} / \mathrm{T}$ boundary was penetrated at 554.5 mbsf.

Holes 762B and $762 \mathrm{C}$ together form one of the most complete Cenozoic sequences ever recovered at a single site (Fig. 4). Only a few calcareous nannofossil zones are missing, and these are exclusively in the Miocene (NN3, NN8, and NN10). Tables 3 and 4 are detailed range charts and biozonation of the Cenozoic at Site 762. Figure 5 plots the first occurrence and last occurrence of biochronologically important species against core positions and biozones at Site 762. The continuity of the section and good preservation of the taxa offered an opportunity to perform a rigorous biomagnetochronologic analysis of the nannofossils at Site 762 by integrating biostratigraphy and magnetostratigraphy. The first stage of this study, a late Miocene-Quaternary biomagnetochronologic synthesis, is presented elsewhere (Siesser et al., chapter 40 , this volume).

\section{Site 763}

Three holes were drilled at this site: 763A, 763B, and 763C (20³5.19-.21'S, $112^{\circ} 12.50-.52^{\prime} \mathrm{E} ; 1368 \mathrm{~m}$ water depth). Hole $763 \mathrm{~A}$ was APC-cored to a depth of $194.9 \mathrm{mbsf}$ (upper Eocene). Hole 763B was XCB-drilled to a depth of 653.5 mbsf (Lower Cretaceous). The $\mathrm{K} / \mathrm{T}$ boundary occurs at $247.0 \mathrm{mbsf}$ in Hole 763B. 
Table 4 (continued).

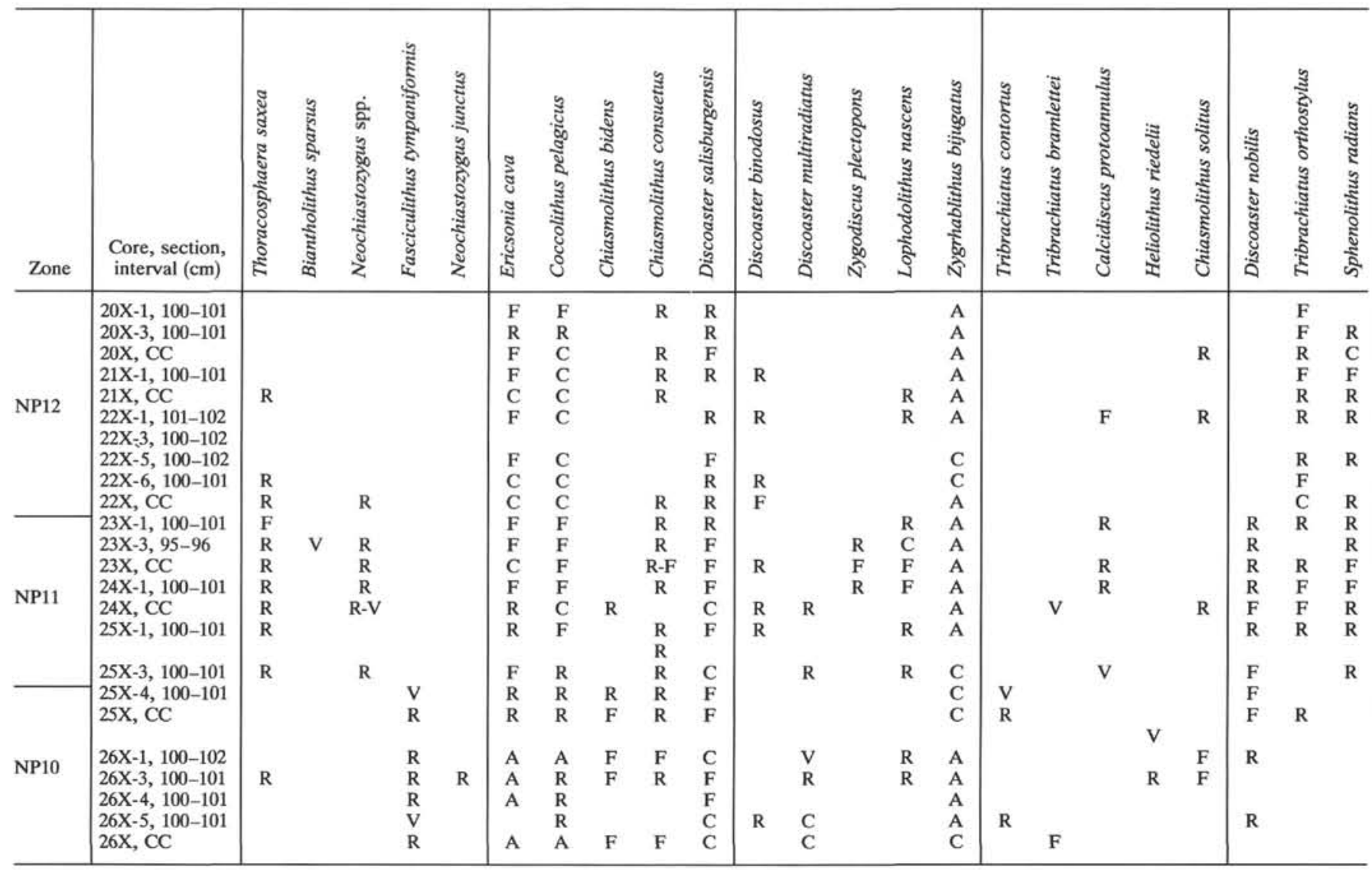

Figure 6 shows the Cenozoic zonation at Site 763. The entire Paleocene, the lower Eocene, and part of the middle Eocene (Zones NP1-NP14) are missing at this site. In addition, Zones NP17 (middle Eocene), NN6-NN9 (middle to upper Miocene), and NN17 (upper Pliocene) are missing. A range chart of species across the NP25-NN4/NN5 interval is given in Table 5 in order to investigate further the Zone NN3 interval missing in our standard section at Site 762 .

\section{Site 764}

Two holes were drilled at this site: $764 \mathrm{~A}$ and $764 \mathrm{~B}$ (16 $33.96^{\prime} \mathrm{S}, 115^{\circ} 27.43^{\prime} \mathrm{E} ; 2697 \mathrm{~m}$ water depth). Hole $764 \mathrm{~A}$ was rotary-cored to a depth of 169 mbsf. A thin (41.5-m-thick) Cenozoic sequence unconformably overlies Maestrichtian sediments at this site. The lowermost Cenozoic section (122764A-5R-3) contains a mixed Eocene-Oligocene assemblage (Fig. 7). Overlying this mixed assemblage is an apparently complete sequence ranging from NP24 (upper Oligocene) to NN4/NN5 (lower to middle Miocene). A major lower-middle Miocene-Quaternary hiatus separates Section 122-764A-1R-7 (NN4/NN5) from Section 122-764A-1R-6 (NN19)

\section{SUMMARY}

Two sites located on the central part of the Exmouth Plateau and four sites located on a northern marginal spur, the Wombat Plateau were drilled during Leg 122. Cenozoic sediments containing abundant, diverse, and generally well-preserved nannofossils were recovered at all sites. Each site was amenable to detailed zonation using Martini's (1971) tropicaltemperate calcareous nannofossil zonation. Species assemblages suggest generally temperate-tropical conditions throughout the Cenozoic.
Minor hiatuses occur throughout the Cenozoic section. Site 762 , however, contains an almost complete Cenozoic section, missing only short intervals in the Miocene. This site may prove to be a useful biostratigraphic and biomagnetochronologic reference section for the eastern Indian Ocean.

\section{ACKNOWLEDGMENTS}

This work was supported by a grant to W. G. Siesser from the NSF/JOI United States Science Program. The U.S. Science Program associated with the Ocean Drilling Program is sponsored by the National Science Foundation and the Joint Oceanographic Institutions, Inc. Any opinions, findings, and conclusions or recommendations expressed in this publication are those of the authors and do not necessarily reflect the views of the National Science Foundation, the Joint Oceanographic Institutions, Inc., or Texas A\&M University.

\section{REFERENCES}

Bukry, D., 1973. Coccolith stratigraphy, eastern equatorial Pacific, Leg 16, Deep Sea Drilling Project. In van Andel, T. H., Heath, G. R., et al., Init. Repts. DSDP, 16: Washington (U.S. Govt. Printing Office), 653-711.

Bukry, D., and Percival, S. F., 1971. New Tertiary calcareous nannofossils. Tulane Stud. Geol. Paleontol., 8:123-146.

Haq, B. U., von Rad, U., O'Connell, S., et al., 1990. Proc. ODP, Init. Repts., 122: College Station, TX (Ocean Drilling Program).

Haq, B. U., von Rad, U., and the ODP Leg 122 Scientific Party, 1988. ODP Leg 122 looks at Exmouth Plateau. Geotimes, 33:10-13.

Martini, E., 1971. Standard Tertiary and Quaternary calcareous nannoplankton zonation. In Farinacci, A. (Ed.), Proc. 2nd Planktonic Conf. Roma: Rome (Ed. Technosci.), 2:739-785. 
Table 4 (continued).

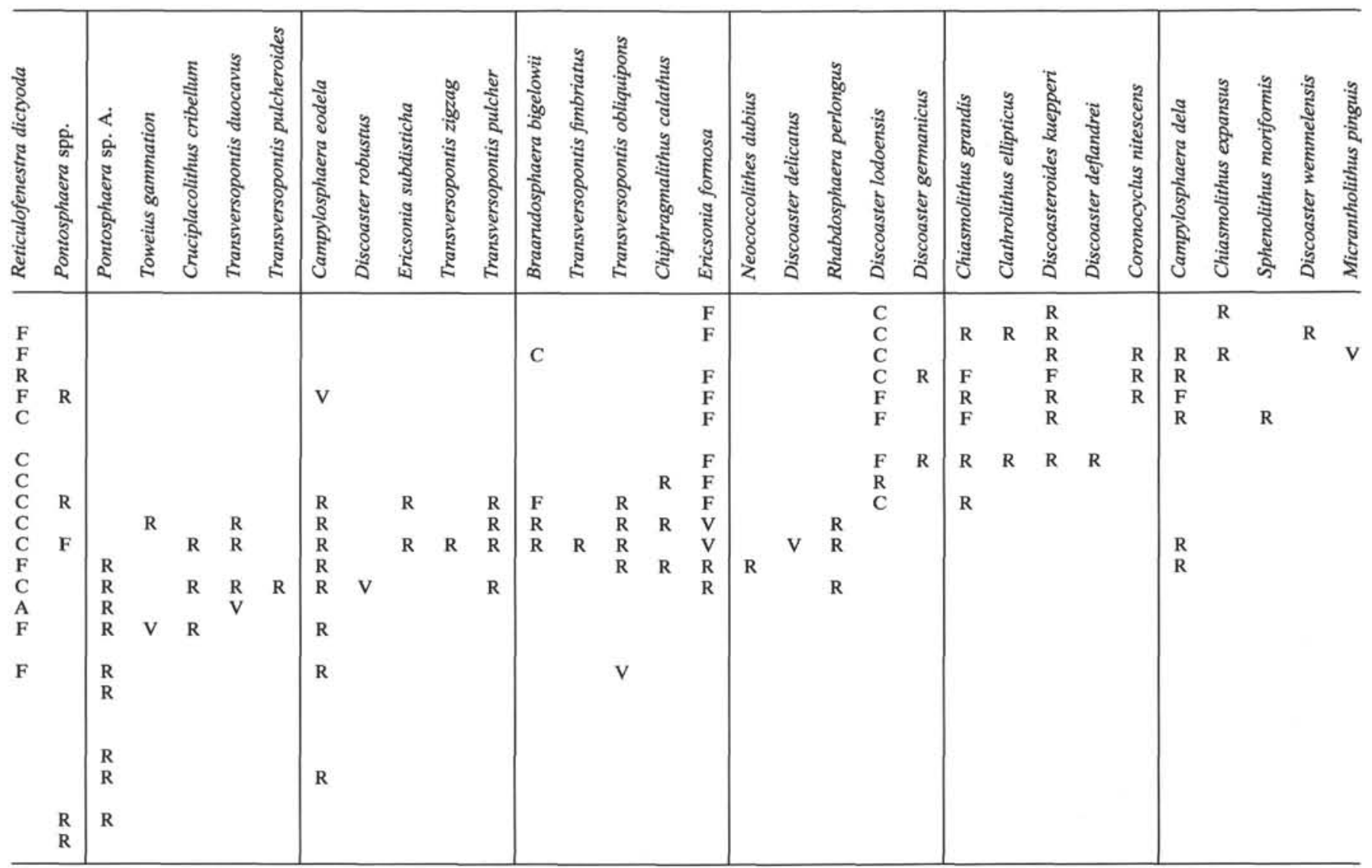

Perch-Nielsen, K., 1985. Cenozoic calcareous nannofossils. In Bolli, H. M., Saunders, J. B., and Perch-Nielsen, K. (Eds.), Plankton Stratigraphy: Cambridge (Cambridge Univ. Press), 427-554.

Romein, A.J.T., 1979. Lineages in early Paleogene calcareous nannoplankton. Utrecht Micropaleontol. Bull., 22:1-231.

Date of initial receipt: 6 April 1990

Date of acceptance: 4 March 1991

Ms 122B-162

\section{APPENDIX}

Cenozoic Calcareous Nannofossils in Exmouth Plateau Sediments

Listed in alphabetical order of species epithets:

Scyphosphaera abelei Rade (1975)

Sphenolithus abies Deflandre in Deflandre and Fert (1954)

Chiphragmalithus acanthodes Bramlette and Sullivan (1961)

Ceratolithus acutus Gartner and Bukry (1974)

Discoaster adamanteus Bramlette and Wilcoxon (1967)

Chiasmolithus altus Bukry and Percival (1971)

Scyphosphaera amphora Deflandre (1942)

Scyphosphaera ampla Kamptner (1955)

Amaurolithus amplificus (Bukry and Percival) Gartner and Bukry (1975)

Markalius apertus Perch-Nielsen (1979)

Scyphosphaera apsteinii dilatata Gaarder (1970)

Scyphosphaera apsteinii Lohmann (1902)

Scyphosphaera aranta Kamptner (1967)

Ceratolithus armatus Müller (1974)

Markalius astroporus (Stradner) Hay and Mohler (1967)

Discoaster asymmetricus Gartner (1969)

Discoaster barbadiensis Tan (1927)

Sphenolithus belemnos Bramlette and Wilcoxon (1967)

Discoaster bellus Bukry and Percival (1971)
Chiasmolithus bidens (Bramlette and Sullivan) Hay and Mohler (1967) Braarudosphaera bigelowii (Gran and Braarud) Deflandre (1947)

Zygrahablithus bijugatus (Deflandre) Deflandre (1959)

Fasciculithus billii Perch-Nielsen (1971)

Discoaster binodosus Martini (1958)

Dictyococcites bisectus (Hay, Mohler and Wade) Bukry and Percival (1971)

Prinsius bisulcus (Stradner) Hay and Mohler (1967)

Amaurolithus bizzarus (Bukry) Gartner and Bukry (1975)

Lapideacassis blackii Perch-Nielsen in Perch-Nielsen and Franz (1977)

Discoaster blackstockae Bukry (1973)

Discoaster braarudii Bukry (1971)

Discoaster bramlettei (Bukry and Percival) Romein (1979)

Tribrachiatus bramlettei (Bronnimann and Stradner) Proto Decima et al. (1975)

Zygodiscus bramlettei Perch-Nielsen (1981)

Discoaster brouweri Tan 1927 emend. Bramlette and Riedel (1954)

Chiphragmalithus calathus Bramlette and Sullivan (1961)

Discoaster calcaris Gartner (1967)

Dictyococcites callidus Perch-Nielsen (1971)

Catinaster calyculus Martini and Bramlette (1963)

Scyphosphaera campanula Deflandre (1942)

Scyphosphaera canescens Kamptner (1955)

Sphenolithus capricormutus Bukry and Percival (1971)

Gephyrocapsa caribbeanica Boudreaux and Hay (1969)

Triquetrorhabdulus carinatus Martini (1965)

Helicosphaera carteri (Wallich) Kamptner (1954)

Ericsonia cava (Hay and Mohler) Perch-Nielsen (1969)

Discoaster challengeri Bramlette and Riedel (1954)

Triquetrorhabdulus challengeri Perch-Nielsen (1977)

Neochiastozyus chiastus (Bramlette and Sullivan) Perch-Nielsen (1971)

Sphenolithus ciperoensis Bramlette and Wilcoxon (1967)

Rhabdosphaera claviger in Murray and Blackman (1898) 


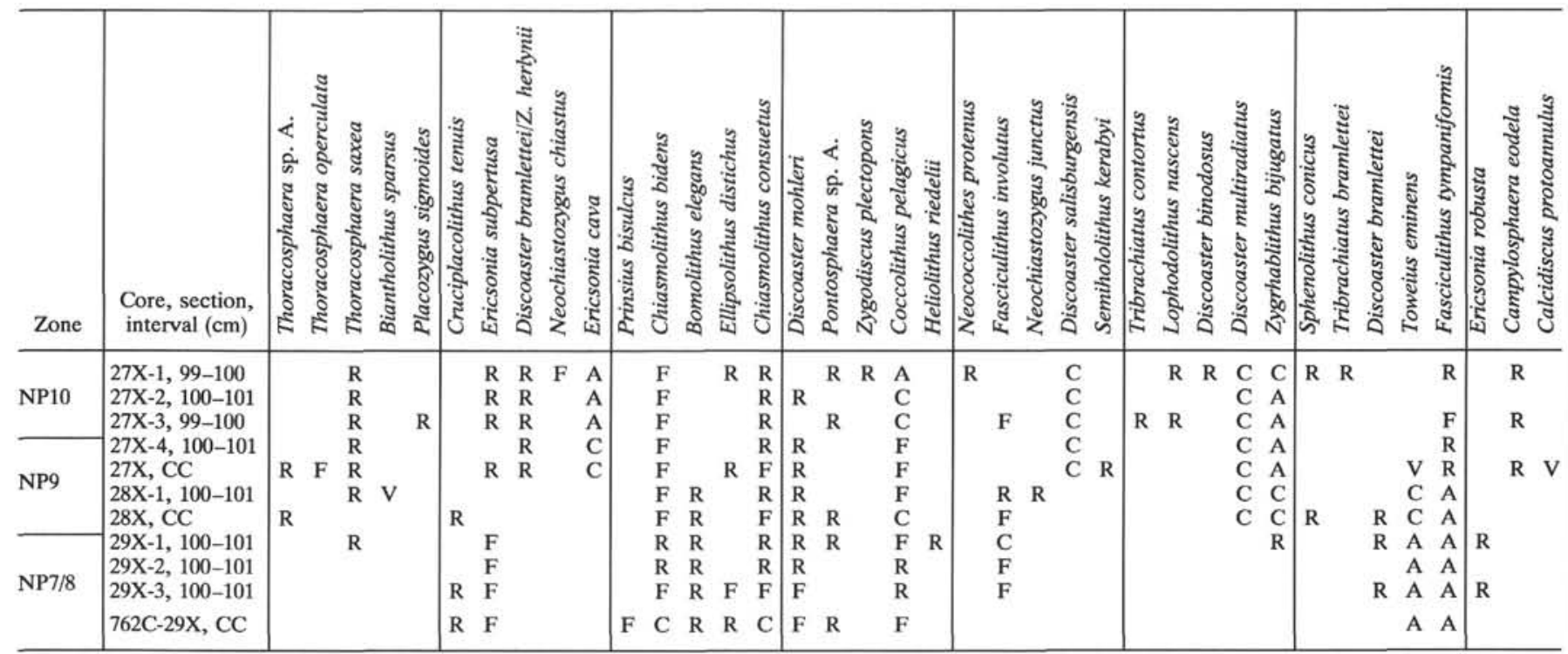

Table 4 (continued).

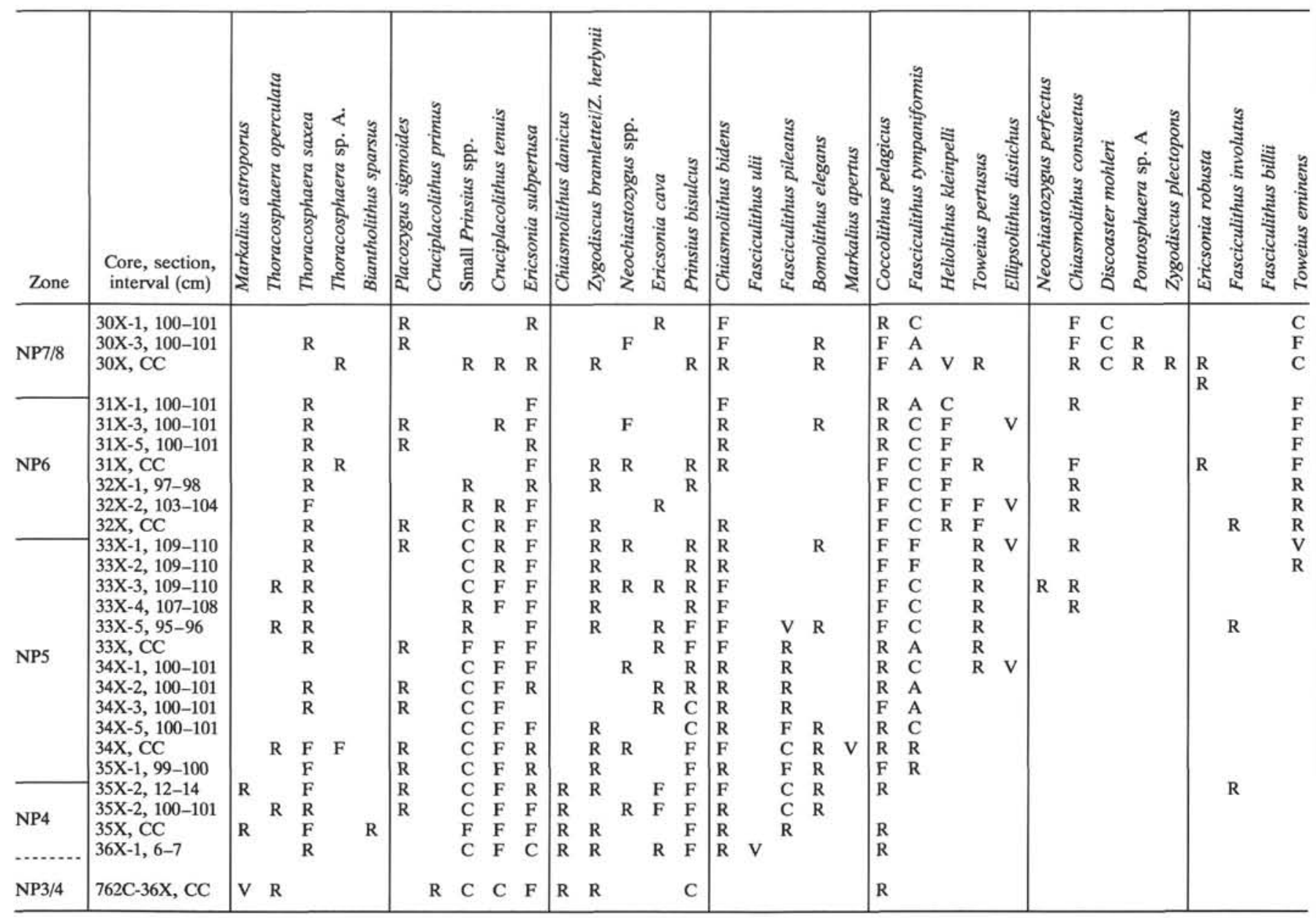


Table 4 (continued).

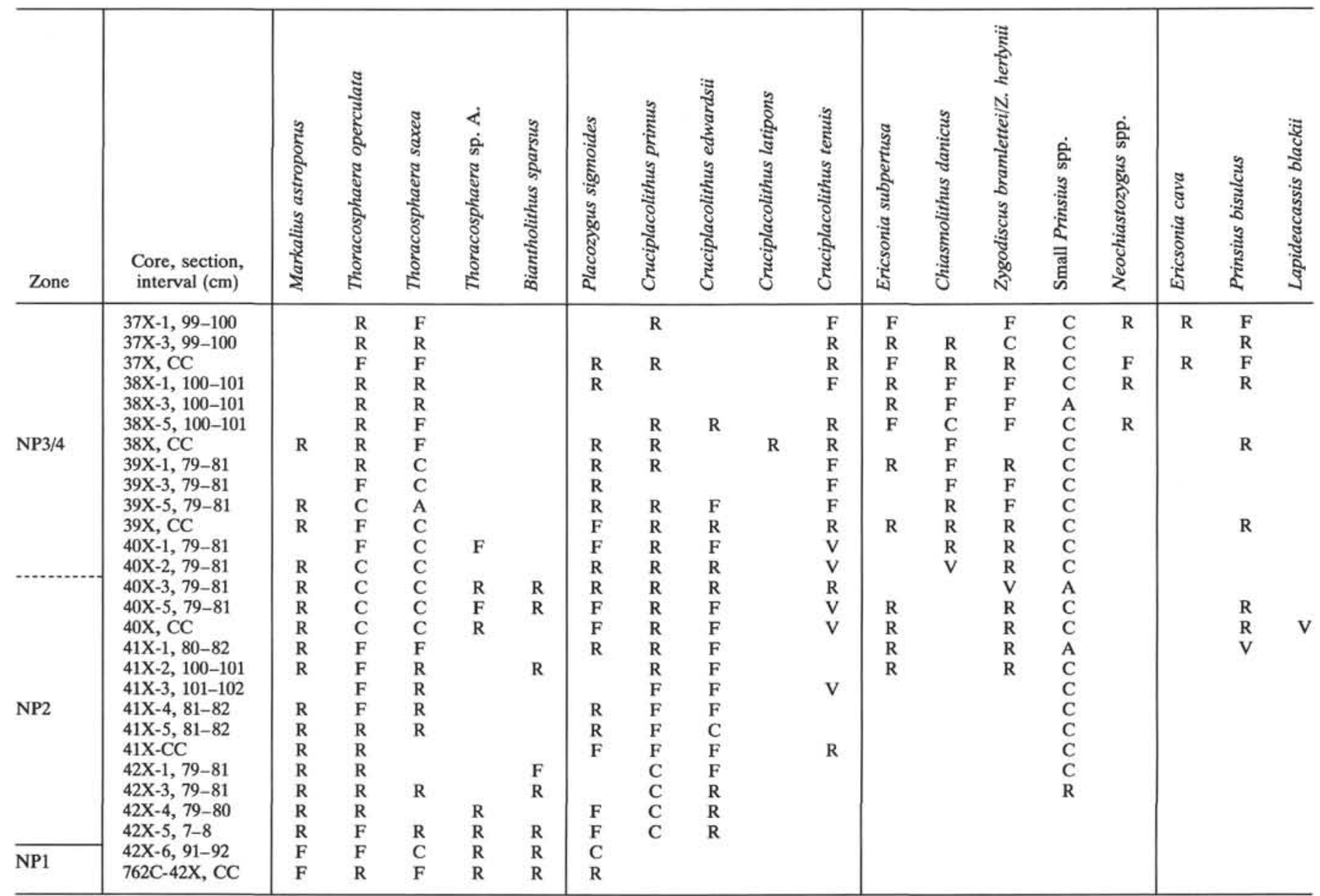

Table 5. Calcareous nannofossils in Hole 763A.

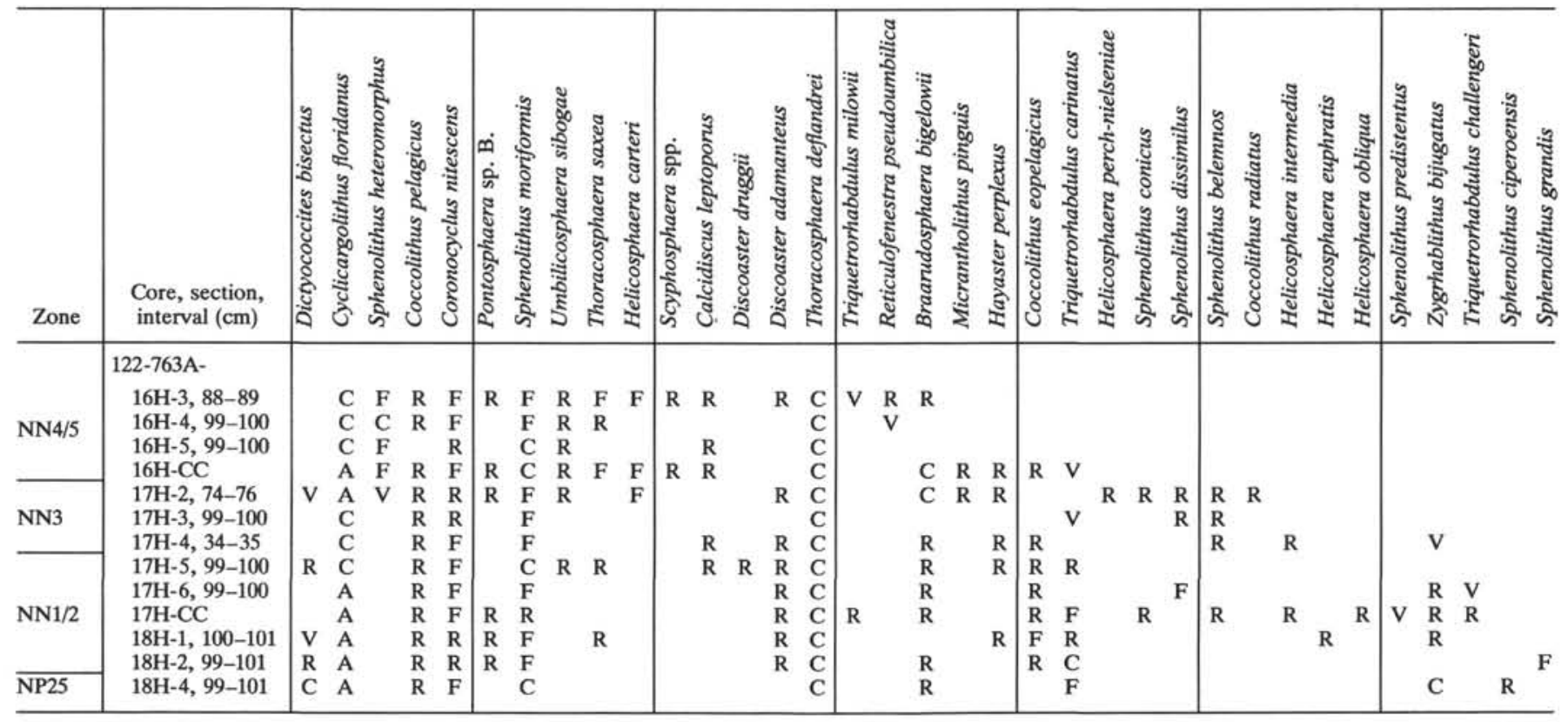


Catinaster coalitus Martini and Bramlette (1963)

Scyphosphaera cohenii Boudreaux and Hay (1969)

Helicosphaera compacta Bramlette and Wilcoxon (1967)

Heliorthus concinnus (Martini) Hay and Mohler (1967)

Neochiastozygus concinnus (Martini) Perch-Nielsen (1971)

Scyphosphaera conica Kamptner (1955)

Sphenolithus conicus Bukry (1971)

Chiasmolithus consuetus (Bramlette and Sullivan) Hay and Mohler (1967)

Tribrachiatus contortus (Stradner) Bukry (1972)

Cruciplacolithus cribellum (Bramlette and Sullivan) Romein (1979)

Nannotetrina cristata (Martini) Perch-Nielsen (1971)

Ceratolithus cristatus Kamptner (1950)

Scyphosphaera cylindrica Kamptner (1955)

Chiasmolithus danicus (Brotzen) Hay and Mohler (1967)

Dictyococcites daviesii (Haq) Perch-Nielsen (1971)

Discoaster decorus (Bukry) Bukry (1973)

Discoaster deflandrei Bramlette and Riedel (1954)

Scyphosphaera deflandrei Müller (1974)

Thoracosphaera deflandrei Kamptner (1956)

Amaurolithus delicatus Gartner and Bukry (1975)

Campylosphaera dela (Bramlette and Sullivan) Hay and Mohler (1967)

Discoaster delicatus Bramlette and Sullivan (1961)

Reticulofenestra dictyoda (Deflandre and Fert) Stradner in Stradner and Edwards (1968)

Pontosphaera discopora Schiller (1925)

Braarudosphaera discula Bramlette and Riedel (1954)

Sphenolithus dissimilus Bukry and Percival (1971)

Sphenolithus distentus (Martini) Bramlette and Wilcoxon (1967)

Ellipsolithus distichus (Bramlette and Sullivan) Sullivan (1964)

Discoaster distinctus Martini (1958)

Discoaster druggii Bramlette and Wilcoxon (1967)

Neococcolithes dubius (Deflandre) Black (1967)

Transversopontis duocavus (Bramlette and Sullivan) Locker (1973)

Cruciplacolithus edwardsii Romein (1979)

Bomolithus elegans Roth (1973)

Clathrolithus ellipticus Deflandre in Deflandre and Fert (1954)

Toweius eminens (Bramlette and Sullivan) Perch-Nielsen (1971)

Pontosphaera enormis (Locker) Perch-Nielsen (1984)

Campylosphaera eodela Bukry and Percival (1971)

Coccolithus eopelagicus (Bramlette and Riedel) Bramlette and Sullivan in Bramlette and Wilcoxon (1967)

Helicosphaera euphratis Haq (1966)

Discoaster exilis Martini and Bramlette (1963)

Scyphosphaera expansa Bukry and Percival (1971)

Chiasmolithus expansus (Bramlette and Sullivan) Gartner (1970)

Ericsonia fenestrata (Deflandre and Fert) Stradner in Stradner and Edwards (1968)

Transversopontis fimbriatus (Bramlette and Sullivan) Locker (1968)

Cyclicargolithus floridanus (Roth and Hay) Bukry (1971)

Ericsonia formosa (Kamptner) Haq (1971)

Discoaster formosus Martini and Worsely (1971)

Scapholithus fossilis Deflandre in Delfandre and Fert (1954)

Nannotetrina fulgens (Stradner) Achutan and Stradner (1969)

Sphenolithus furcatolithoides Locker (1967)

Toweius gammation (Bramlette and Sullivan) Romein (1979)

Discoaster gemmeus Stradner (1961)

Corannulus germanicus Stradner (1962)

Discoaster germanicus Martini (1958)

Chiasmolithus gigas (Bramlette and Sullivan) Radomski (1968)

Scyphosphaera gladstonensis Rade (1975)

Scyphosphaera globulata Bukry and Percival (1971)

Scyphosphaera globulosa Kamptner (1955)

Chiasmolithus grandis (Bramlette and Riedel) Gartner (1970)

Sphenolithus grandis Haq and Berggren (1978)

Helicosphaera granulata Bukry and Percival (1971)

Discoaster hamatus Martini and Bramlette (1963)

Reticulofenestra haqii Backman (1978)

Fasciculithus hayi Haq (1971)

Thoracosphaera heimi (Lohmann) Kamptner (1920)

Zygodiscus herlynii Sullivan (1964)

Sphenolithus heteromorphus Deflandre (1953)

Emiliania huxleyi (Lohmann) Hay and Mohler in Hay et al. (1967)
Rhabdosphaera inflata Bramlette and Sullivan (1961)

Discoaster intercalaris Bukry (1971)

Sphenolithus intercalaris Martini (1976)

Helicosphaera intermedia Martini (1965)

Scyphosphaera intermedia Deflandre (1942)

Markalius inversus (Deflandre) Bramlette and Martini (1964)

Triquetrorhabdulus inversus Bukry and Bramlette (1969)

Fasciculithus involutus Bramlette and Sullivan (1961)

Peritrachelina joidesa Bukry and Bramlette (1968)

Neochiastozygus junctus (Bramlette and Sullivan) Perch-Nielsen (1971)

Scyphosphaera kamptneri Müller (1974)

Semihololithus kerabyi Perch-Nielsen (1971)

Heliolithus kleinpelli Sullivan (1964)

Discoasteroides kuepperi (Stradner) Bramlette and Sullivan (1961)

Discoaster kugleri Martini and Bramlette (1963)

Pseudoemiliania lacunosa (Kamptner) Gartner (1969)

Scyphosphaera lagena Kamptner (1955)

Cruciplacolithus latipons Romein (1970)

Calcidiscus leptoporus (Murray and Blackman) Loeblich and Tappan (1978)

Discoaster lodoensis Bramlette and Riedel (1961)

Rhabdosphaera longistylis Schiller (1925)

Helicosphaera lophota Bramlette and Sullivan (1961)

Cyclococcolithus luminis Sullivan (1965)

Ellipsolithus macellus (Bramlette and Sullivan) Sullivan (1964)

Calcidiscus macintyrei (Bukry and Bramlette) Loeblich and Tappan (1978)

Fasciculithus magnicordis Romein (1979)

Prinsius martinii (Perch-Nielsen) Haq (1971)

Triquetrorhabdulus milowii Bukry (1971)

Reticulofenestra minuta Roth (1970)

Reticulofenestra minutula (Gartner) Haq and Berggren (1978)

Lanternithus minutus Stradner (1962)

Discoaster mohleri Bukry and Percival (1971)

Sphenolithus moriformis (Bronnimann and Stradner) Bramlette and Wilcoxon (1967)

Pontosphaera multipora (Kamptner) Roth (1970)

Discoaster multiradiatus Bramlette and Riedel (1954)

Lophodolithus nascens Bramlette and Sullivan (1961)

Sphenolithus neoabies Bukry and Bramlette (1969)

Discoaster neohamatus Bukry and Bramlette (1969)

Discoaster neorectus Bukry (1971)

Coronocyclus nitescens (Kamptner) Bramlette and Wilcoxon (1967)

Discoaster nobilis Martini (1961)

Discoaster nodifer (Bramlette and Riedel) Bukry (1973)

Chiasmolithus oamaruensis (Deflandre) Hay, Mohler and Wade (1966)

Helicosphaera obliqua Bramlette and Wilcoxon (1967)

Transversopontis obliquipons (Deflandre) Hay, Mohler and Wade (1966)

Gephyrocapsa oceanica Kamptner (1943)

Thoracosphaera operculata Bramlette and Martini (1964)

Scyphosphaera oremesa Kamptner (1967)

Tribrachiatus orthostylus Shamrai (1963)

Scyphosphaera pacifica Rade (1975)

Coccolithus pelagicus (Wallich) Schiller (1930)

Scyphosphaera penna Kamptner (1955)

Discoaster pentaradiatus Tan 1927 emend. Bramlette and Riedel (1954)

Helicosphaera perch-nielseniae Haq (1971)

Neochiastozygus perfectus Perch-Nielsen (1971)

Rhabdosphaera perlongus (Deflandre) in Grasse (1952)

Hayaster perplexus (Bramlette and Riedel) Bukry (1973)

Toweius pertusus (Sullivan) Romein (1979)

Fasciculithus pileatus Bukry (1973)

Micrantholithus pinguis Bramlette and Sullivan (1961)

Scyphosphaera piriformis Kamptner (1955)

Pontosphaera plana (Bramlette and Sullivan) Haq (1971)

Zygodiscus plectopons Bramlette and Sullivan (1961)

Scyphosphaera porosa Kamptner (1967)

Sphenolithus predistentus Bramlette and Wilcoxon (1967)

Amaurolithus primus (Bukry and Percival) Gartner and Bukry (1975)

Cruciplacolithus primus Perch-Nielsen (1977) 
Rhabdosphaera procera Martini (1969)

Scyphosphaera procera Kamptner (1955)

Thoracosphaera prolata Bukry and Bramlette (1969)

Neococcolithes protenus (Bramlette and Sullivan) Black (1967)

Calcidiscus protoannulus (Gartner) Loeblich and Tappan (1978)

Sphenolithus pseudoradians Bramlette and Wilcoxon (1967)

Reticulofenestra pseudoumbilica (Gartner) Gartner (1969)

Transversopontis pulcher (Deflandre) Hay, Mohler and Wade (1966)

Transversopontis pulcheroides (Sullivan) Baldi-Beke (1971)

Scyphosphaera pulcherrima Deflandre (1942)

Pontosphaera punctosa (Bramlette and Sullivan) Perch-Nielsen (1984)

Discoaster quinqueramus Gartner (1969)

Sphenolithus radians Deflandre (1952)

Coccolithus radiatus Kamptner (1955)

Scyphosphaera recta (Deflandre) Kamptner (1955)

Scyphosphaera recurvata Deflandre (1942)

Isthmolithus recurvus Deflandre in Deflandre and Fert (1954)

Helicosphaera reticulata Bramlette and Wilcoxon (1967)

Reticulofenestra reticulata (Gartner and Smith) Roth and Thierstein (1967)

Scapholithus rhombiformis Hay and Mohler (1967)

Heliolithus riedelii Bramlette and Sullivan (1961)

Ericsonia robusta (Bramlette and Sullivan) Perch-Nielsen (1977)

Discoaster robustus Haq (1969)

Ceratolithus rugosus Bukry and Bramlette (1968)

Triquetrorhabdulus rugosus Bramlette and Wilcoxon (1967)

Discoaster saipanensis Bramlette and Riedel (1954)

Discoaster salisburgensis Stradner (1961)

Thoracosphaera saxea Stradner (1961)

Discolithina segmenta Bukry and Percival (1971)

Bramletteius serraculoides Gartner (1969)

Umbilicosphaera sibogae (Weber-van Bosse) Gaarder (1970)

Placozygus sigmoides (Bramlette and Sullivan) Romein (1979)
Discoaster signus Bukry (1971)

Hayella situliformis Gartner (1969)

Chiasmolithus solitus (Bramlette and Sullivan) Locker (1968)

Biantholithus sparsus Bramlette and Martini (1964)

Sphenolithus spiniger Bukry (1971)

Blackites spinosus (Deflandre and Fert) Hay and Towe (1962)

Cruciplacolithus staurion (Bramlette and Sullivan) Gartner (1971)

Discoaster strictus Stradner (1961)

Ericsonia subdisticha (Roth and Hay) Roth in Baumann and Roth (1969)

Discoaster sublodoensis Bramlette and Sullivan (1961)

Ericsonia subpertusa Hay and Mohler (1967)

Discoaster surculus Martini and Bramlette (1963)

Discoaster tamalis Kamptner (1967)

Discoaster tanii Bramlette and Riedel (1954)

Ceratolithus telesmus Norris (1965)

Blackites tenuis (Bramlette and Sullivan) Bybell (1975)

Cruciplacolithus tenuis (Stradner) Hay and Mohler in Hay et al. (1967)

Amaurolithus tricorniculatus (Gartner) Gartner and Bukry (1975)

Discosphaera tubifer (Murray and Blackman) Ostenfeld (1900)

Scyphosphaera tubifera Kamptner (1955)

Scyphosphaera turris Kamptner (1955)

Fasciculithus tympaniformis Hay and Mohler in Hay et al. (1967)

Fasciculithus ulii Perch-Nielsen (1971)

Reticulofenestra umbilica (Levin) Martini and Ritzkowski (1968)

Discoaster variabilis Martini and Bramlette (1963)

Scyphosphaera ventriosa Martini (1968)

Pontosphaera versa (Bramlette and Sullivan) Sherwood (1974)

Rhabdosphaera vitreus Deflandre in Deflandre and Fert (1954)

Helicosphaera wallichii (Lohmann) Boudreaux and Hay (1969)

Discoaster wemmelensis Achutan and Stradner (1969)

Helicosphaera wilcoxonii Gartner (1971)

Transversopontis zigzag Roth and Hay in Hay et al. (1967) 
W. G. SIESSER, T. J. BRALOWER

HOLE 760A

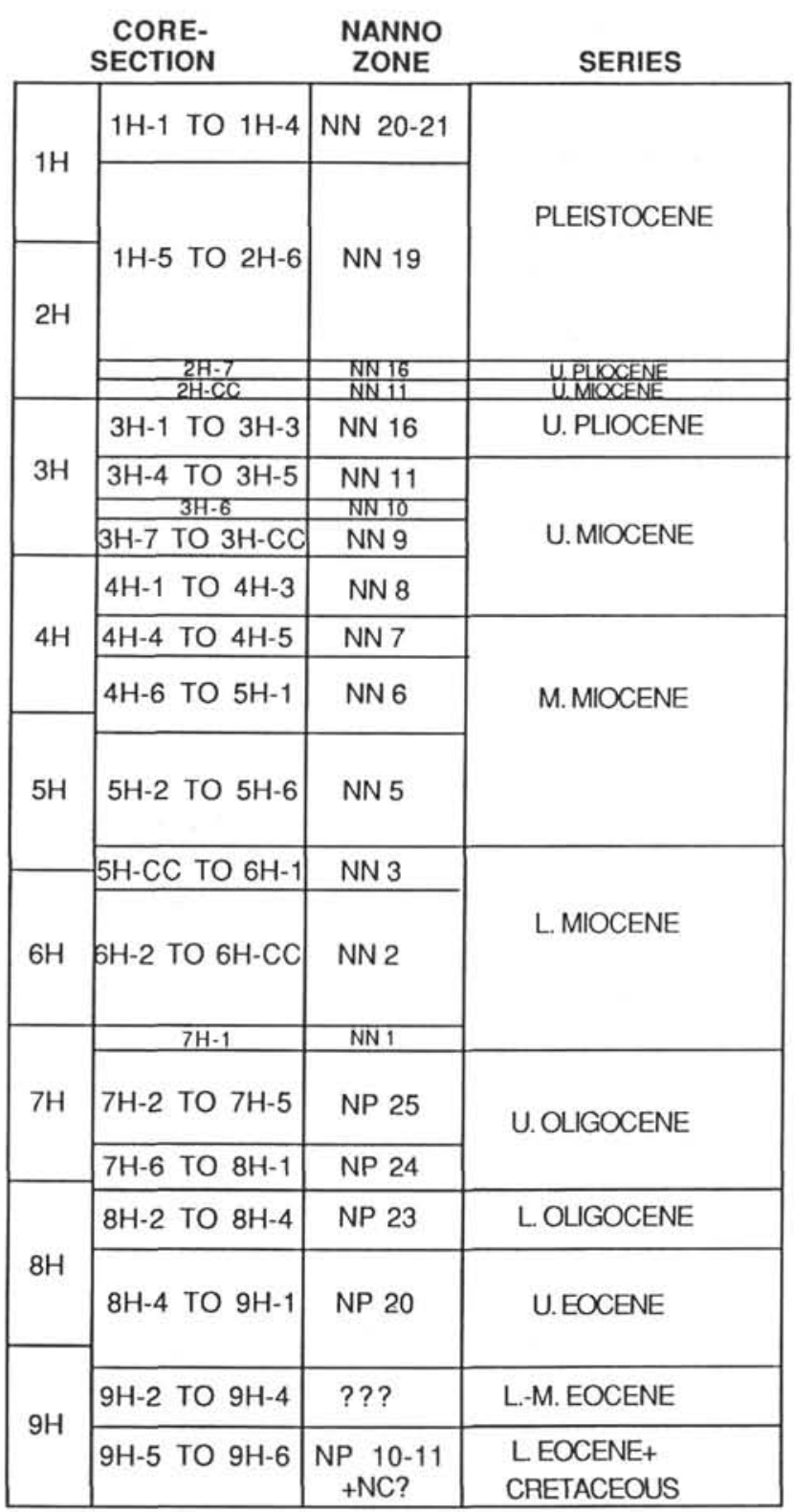

Figure 2. Calcareous nannofossil zonation (Martini, 1971) of Hole $760 \mathrm{~A}$, Wombat Plateau. 


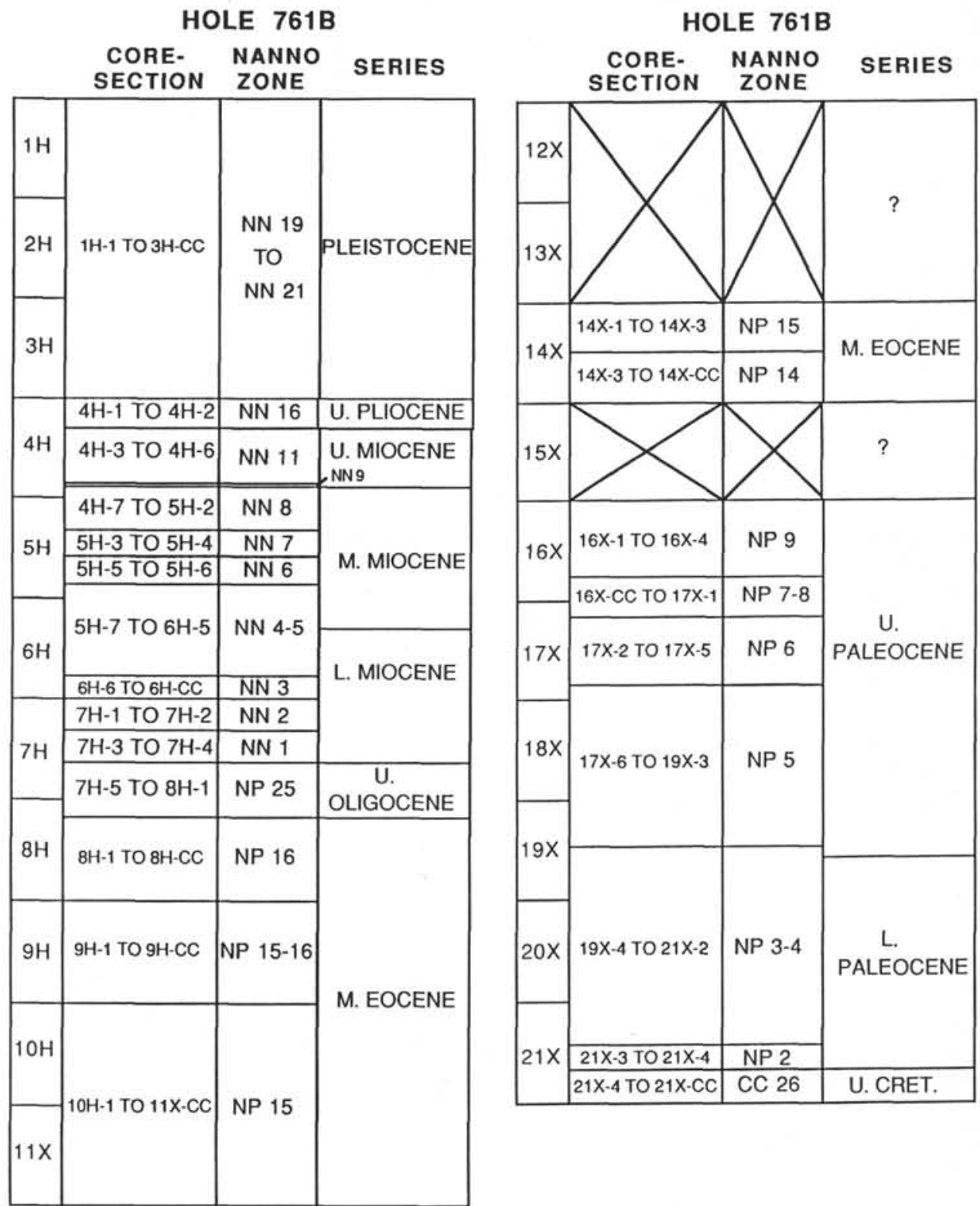

Figure 3. Calcareous nannofossil zonation (Martini, 1971) of Hole 761B, Wombat Plateau. 
HOLE 762B

\begin{tabular}{|c|c|c|c|}
\hline & $\begin{array}{l}\text { CORE- } \\
\text { SECTION }\end{array}$ & $\begin{array}{l}\text { NANNO } \\
\text { ZONE }\end{array}$ & SERIES \\
\hline $1 \mathrm{H}$ & $1 \mathrm{H}-\mathrm{CC}$ & NN 20-21 & \multirow{3}{*}{ PLEISTOCENE } \\
\hline $2 \mathrm{H}$ & \multirow{2}{*}{$2 \mathrm{H}-1$ TO $4 \mathrm{H}-3$} & \multirow{2}{*}{ NN 19} & \\
\hline $3 \mathrm{H}$ & & & \\
\hline $4 \mathrm{H}$ & $4 \mathrm{H}-4 \mathrm{TO} 5 \mathrm{H}-2$ & NN 17.18 & \multirow{4}{*}{ U. PLIOCENE } \\
\hline $5 \mathrm{H}$ & \multirow{3}{*}{$5 \mathrm{H}-3$ TO $8 \mathrm{H}-1$} & \multirow{3}{*}{ NN 16} & \\
\hline $6 \mathrm{H}$ & & & \\
\hline $7 \mathrm{H}$ & & & \\
\hline $8 \mathrm{H}$ & $8 \mathrm{H}-3 \mathrm{TO} 8 \mathrm{H}-\mathrm{CC}$ & NN 14-15 & \multirow{4}{*}{ L. PLIOCENE } \\
\hline $9 \mathrm{H}$ & \multirow[b]{2}{*}{$9 \mathrm{H}-1$ TO $11 \mathrm{H}-2$} & \multirow[b]{2}{*}{ NN 13} & \\
\hline $10 \mathrm{H}$ & & & \\
\hline $11 \mathrm{H}$ & $11 \mathrm{H}-3$ TO $11 \mathrm{H}-\mathrm{CC}$ & NN 12 & \\
\hline $12 \mathrm{H}$ & $12 \mathrm{H}-1$ TO $13 \mathrm{H}-2$ & NN 11 & U. MIOCENE \\
\hline $13 \mathrm{H}$ & $13 \mathrm{H}-3$ TO $13 \mathrm{H}-\mathrm{CC}$ & NN 9 & \multirow{3}{*}{ M. MIOCENE } \\
\hline $14 \mathrm{H}$ & $14 \mathrm{H}-1$ TO $14 \mathrm{H} \cdot 5$ & NN 6-7 & \\
\hline $15 \mathrm{H}$ & $14 \mathrm{H}-6$ TO $15 \mathrm{H}-4$ & NN 4-5 & \\
\hline $16 \mathrm{H}$ & $15 \mathrm{H}-5$ TO $16 \mathrm{H}-5$ & NN 1-2 & L. MIOCENE \\
\hline \multirow{2}{*}{$17 \mathrm{H}$} & $16 \mathrm{H}-6$ TO $17 \mathrm{H}-4$ & NP $24-25$ & U. OLGOCENE \\
\hline & $17 \mathrm{H}-5$ TO $18 \mathrm{H}-4$ & NP 23 & \multirow{3}{*}{ L. OLIGOCENE } \\
\hline & $18 \mathrm{H}-5$ TO $19 \mathrm{H}-5$ & NP 22 & \\
\hline & $19 \mathrm{H}-5 \mathrm{TO} \quad 19 \mathrm{H} \cdot \mathrm{CC}$ & NP21 & \\
\hline
\end{tabular}

HOLE 762C

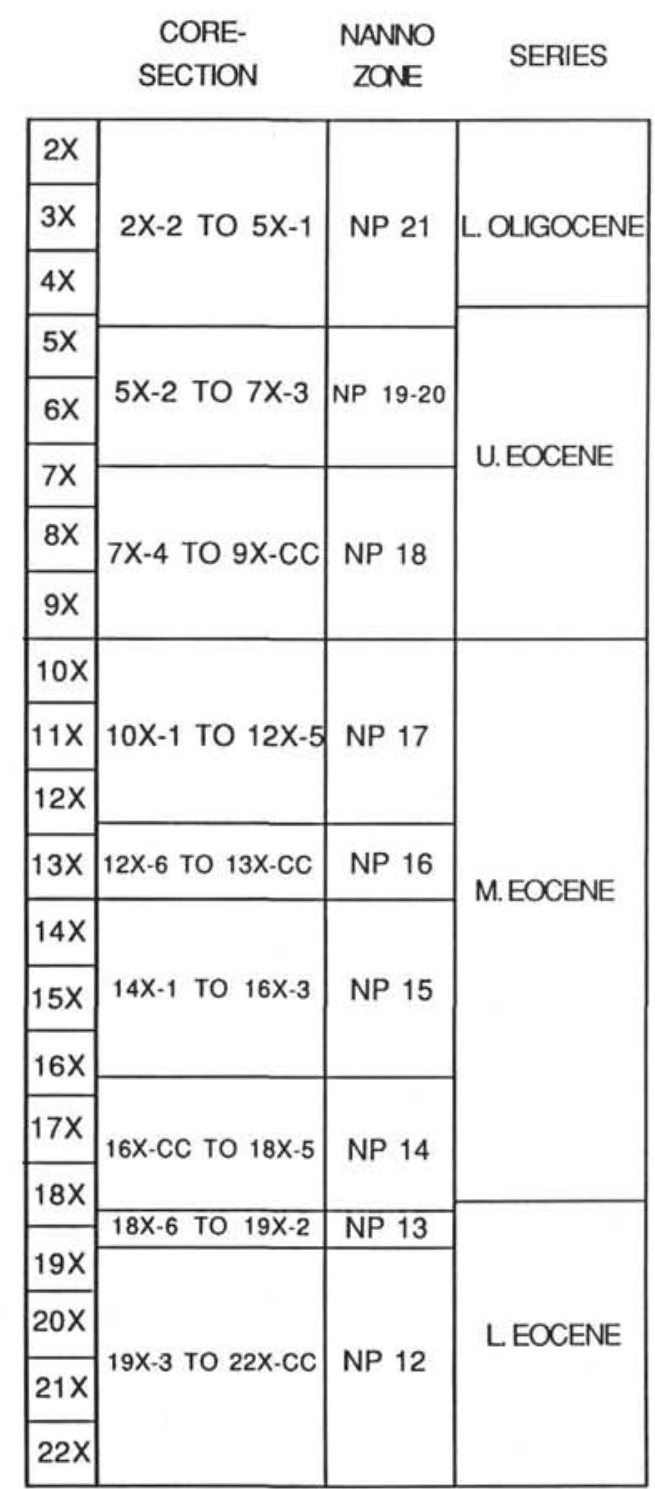

HOLE $762 \mathrm{C}$

CORE-

SECTION TONE SERIES

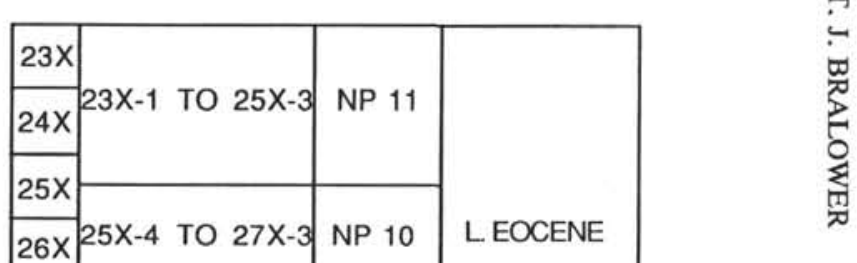

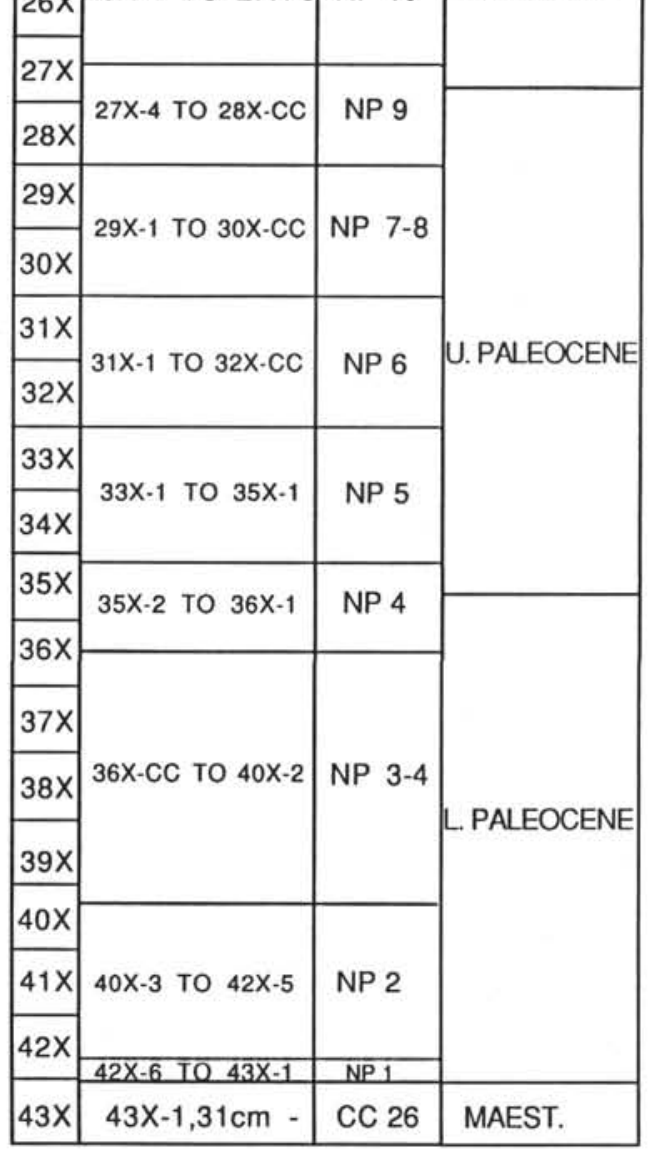

\footnotetext{
Figure 4. Calcareous nannofossil zonation (Martini, 1971) of Holes 762B and 762C, central Exmouth Plateau.
} 


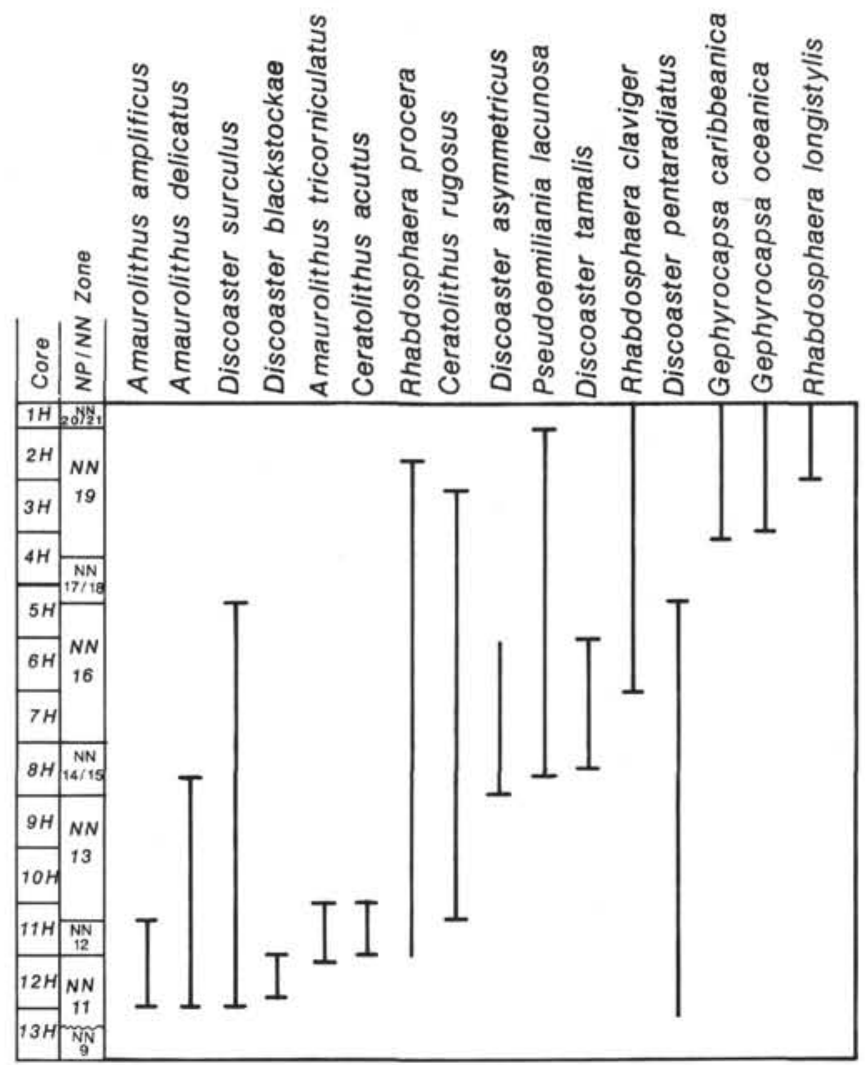

Figure 5. First occurrences (FO) and last occurrences (LO) of biochronologically important Cenozoic calcareous nannofossil species at Site 762 plotted against core position and against Martini's (1971) nannofossil zonation. Lack of a horizontal line at the end of a vertical range bar indicates that the precise $\mathrm{FO} / \mathrm{LO}$ of that species is less confidently documented. 
W. G. SIESSER, T. J. BRALOWER

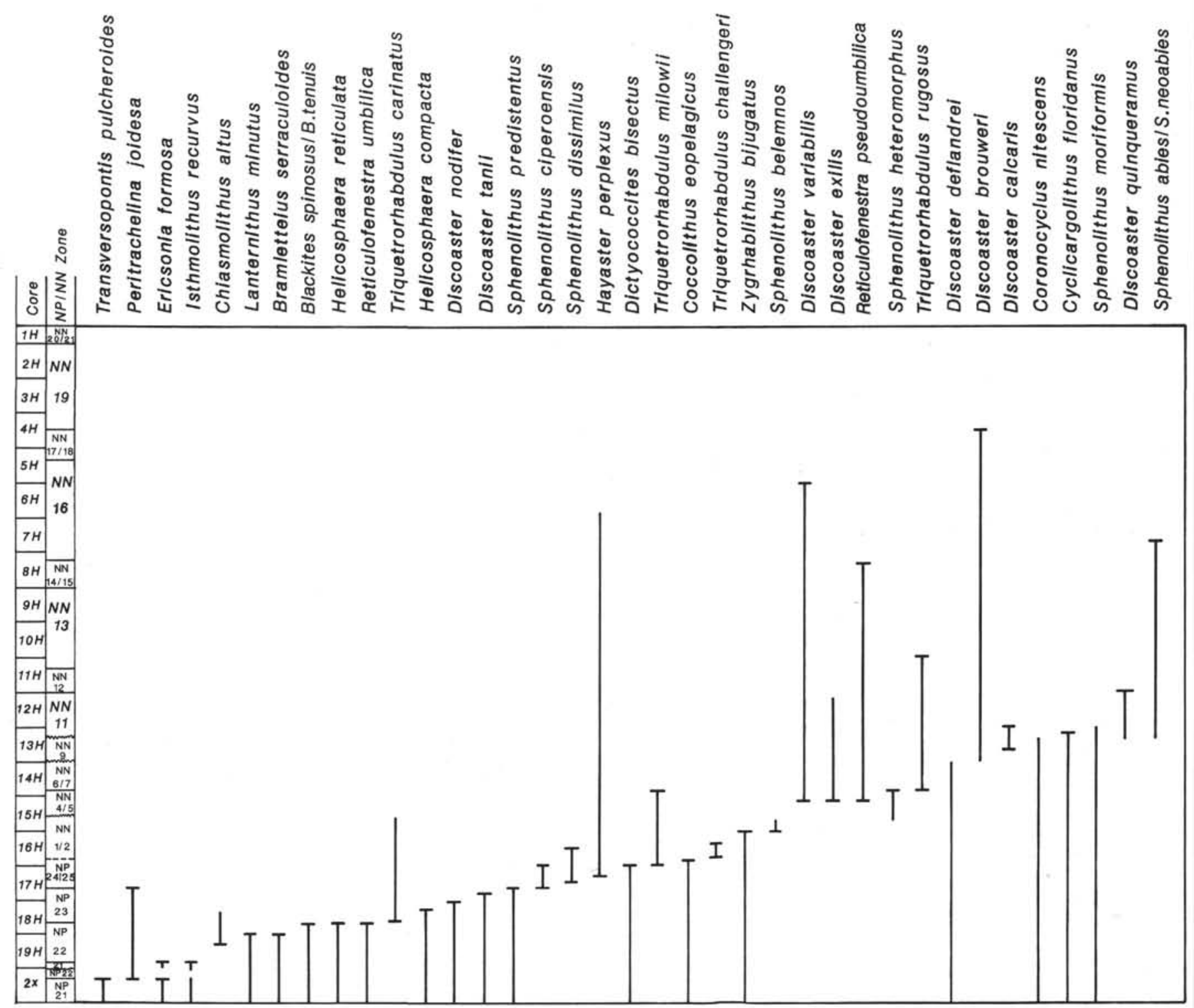

Figure 5 (continued). 


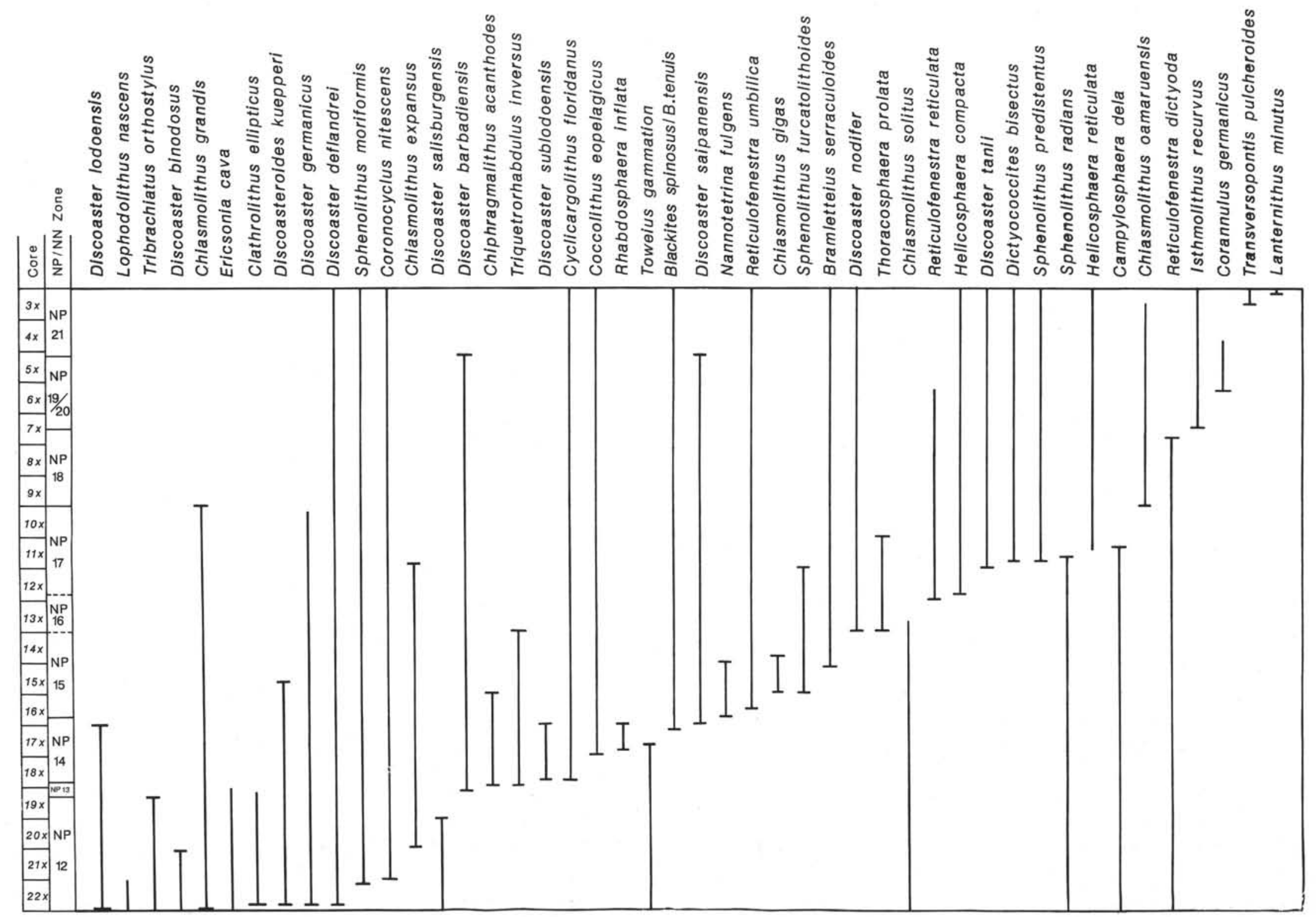

Figure 5 (continued). 
W. G. SIESSER, T. J. BRALOWER

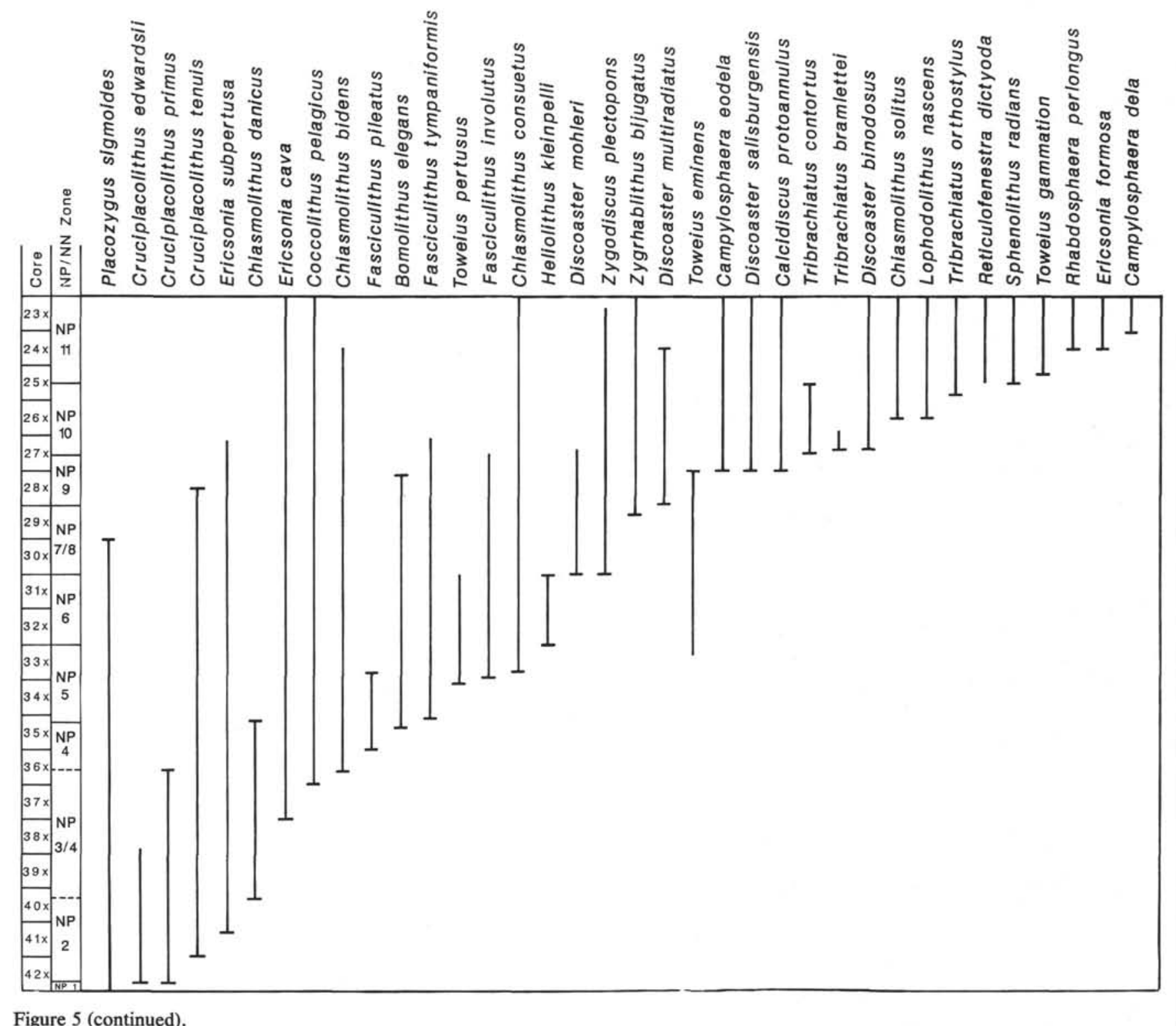

624 
HOLE 763A

\begin{tabular}{|c|c|c|c|}
\hline & $\begin{array}{l}\text { CORE- } \\
\text { SECTION }\end{array}$ & $\begin{array}{l}\text { NANNO } \\
\text { ZONE }\end{array}$ & SERIES \\
\hline $\mathrm{IH}$ & $1 \mathrm{H}-\mathrm{CC}$ TO $2 \mathrm{H}-3$ & NN 20-21 & \multirow{4}{*}{ PLEISTOCENE } \\
\hline $2 \mathrm{H}$ & \multirow{3}{*}{$2 \mathrm{H}-3$ TO $5 \mathrm{H}-1$} & \multirow{3}{*}{ NN 19} & \\
\hline $3 \mathrm{H}$ & & & \\
\hline $4 \mathrm{H}$ & & & \\
\hline $5 \mathrm{H}$ & $5 \mathrm{H}-2$ TO $5 \mathrm{H}-\mathrm{CC}$ & NN 18 & \multirow{4}{*}{ U. PLIOCENE } \\
\hline $6 \mathrm{H}$ & \multirow{3}{*}{$6 \mathrm{H}-1 \mathrm{TO} 8 \mathrm{H}-\mathrm{CC}$} & \multirow{3}{*}{ NN 16} & \\
\hline $7 \mathrm{H}$ & & & \\
\hline $8 \mathrm{H}$ & & & \\
\hline $9 \mathrm{H}$ & $\begin{array}{l}\frac{9 \mathrm{H}-1 \text { TO } 9 \mathrm{H}-5}{9 \mathrm{H}-6 \mathrm{TO} 9 \mathrm{H}-\mathrm{CC}} \\
\end{array}$ & $\begin{array}{c}\text { NN 14-15 } \\
\text { NN } 13\end{array}$ & \multirow{3}{*}{ L. PLIOCENE } \\
\hline $10 \mathrm{H}$ & \multirow{2}{*}{$10 \mathrm{H}-1$ TO $11 \mathrm{H}-\mathrm{CC}$} & \multirow{2}{*}{ NN 12} & \\
\hline $11 \mathrm{H}$ & & & \\
\hline $12 \mathrm{H}$ & \multirow{3}{*}{$12 \mathrm{H}-1$ TO $14 \mathrm{H}-\mathrm{CC}$} & \multirow{3}{*}{ NN 11} & \multirow{4}{*}{ U. MIOCENE } \\
\hline $13 \mathrm{H}$ & & & \\
\hline $14 \mathrm{H}$ & & & \\
\hline $15 \mathrm{H}$ & $15 \mathrm{H}-1$ TO $16 \mathrm{H}-3$ & NN 10 & \\
\hline $16 \mathrm{H}$ & $16 \mathrm{H}-3$ TO $17 \mathrm{H}-1$ & NN 4-5 & M. MIOCENE \\
\hline $17 \mathrm{H}$ & $17 \mathrm{H}-2$ TO $17 \mathrm{H}-4$ & NN3 & \multirow[t]{2}{*}{ L. MIOCENE } \\
\hline $18 \mathrm{H}$ & $17 \mathrm{H}-5$ TO $18 \mathrm{H}-2$ & NN 1-2 & \\
\hline & $\begin{array}{r}18 \mathrm{H}-4 \text { TO18H-CC } \\
19 \mathrm{H}-2 \mathrm{TO} \quad 19 \mathrm{H}-4\end{array}$ & $\frac{\text { NP } 25}{\text { NP } 24}$ & U.OUGOCENE \\
\hline 年 & $19 \mathrm{H}-6$ TO $20 \mathrm{H}-2$ & NP 23 & \multirow{2}{*}{ L. OLIGOCENE } \\
\hline $20 \mathrm{H}$ & $20 \mathrm{H}-6$ & NP 22 & \\
\hline $21 \mathrm{H}$ & 20H-CC TO 2X-1 & NP 21 & $\begin{array}{l}\text { L.OLGOCENE } \\
\text { - U. EOCENE }\end{array}$ \\
\hline
\end{tabular}

Figure 6. Calcareous nannofossil zonation (Martini, 1971) of Holes 763A and 763B, Wombat Plateau.
HOLE 763B

\begin{tabular}{|c|c|c|c|}
\hline & $\begin{array}{l}\text { CORE- } \\
\text { SECTION }\end{array}$ & $\begin{array}{l}\text { NANNO } \\
\text { ZONE }\end{array}$ & SERIES/STAGE \\
\hline $2 x$ & \multirow{2}{*}{$\frac{2 X-1}{2 X-2 \text { TO } 3 X-C C}$} & \multirow{2}{*}{$\begin{array}{l}\text { NP21 } \\
\text { NP } 20\end{array}$} & \multirow{4}{*}{ U.EOCENE } \\
\hline $3 x$ & & & \\
\hline $4 X$ & $4 \mathrm{X}-1$ TO $4 \mathrm{X}-\mathrm{CC}$ & NP $19-20$ & \\
\hline $5 X$ & $5 X-1$ TO $5 X-c c$ & NP 18 & \\
\hline $6 x$ & $6 \mathrm{X}-1$ TO $6 \mathrm{X}-5$ & NP15-16 & \multirow{2}{*}{ M. EOCENE } \\
\hline $7 x$ & $6 \mathrm{X}-\mathrm{CC}$ TO $7 \mathrm{X}-\mathrm{CC}$ & NP 15 & \\
\hline $8 x$ & $8 X-1$ TO $10 X-C C$ & & U. CAMPANIAN \\
\hline
\end{tabular}


W. G. SIESSER, T. J. BRALOWER

HOLE 764A

\begin{tabular}{|c|c|c|c|}
\hline & $\begin{array}{l}\text { CORE- } \\
\text { SECTION }\end{array}$ & $\begin{array}{l}\text { NANNO } \\
\text { ZONE }\end{array}$ & SERIES \\
\hline \multirow[b]{2}{*}{$1 \mathrm{R}$} & $1 \mathrm{~B}-1$ & NN 20.21 & \multirow[b]{2}{*}{ PLEISTOCENE } \\
\hline & 1R-2 TO $1 \mathrm{R}-6$ & NN 19 & \\
\hline \multirow{2}{*}{$2 \mathrm{R}$} & \multirow{2}{*}{$1 \mathrm{R}-7$ TO $2 \mathrm{R}-\mathrm{CC}$} & \multirow{2}{*}{ NN 4-5 } & M. MIOCENE \\
\hline & & & \multirow{3}{*}{ L. MIOCENE } \\
\hline \multirow{3}{*}{$3 R$} & 3R-1 TO 3R-3 & NN 3 & \\
\hline & $3 \mathrm{R}-4$ & $N N 1-2$ & \\
\hline & 3R-5 TO 3R-CC & NP 25 & \multirow[b]{2}{*}{ U. OLIGOCENE } \\
\hline 4R & $4 \mathrm{R}-\mathrm{CC}$ & NP 24 & \\
\hline \multirow{2}{*}{$5 R$} & $5 \mathrm{R}-3,10 \mathrm{~cm}$ & $\begin{array}{c}\text { mixed } \\
\text { Olig-Eoc } \\
\end{array}$ & OLIGO. TO EOCENE \\
\hline & $5 \mathrm{R}-3, \quad 55 \mathrm{~cm}$ & $\mathrm{CC} 25$ & U. MAEST. \\
\hline
\end{tabular}

Figure 7. Calcareous nannofossil zonation (Martini, 1971) of Hole $764 \mathrm{~A}$, Wombat Plateau. 

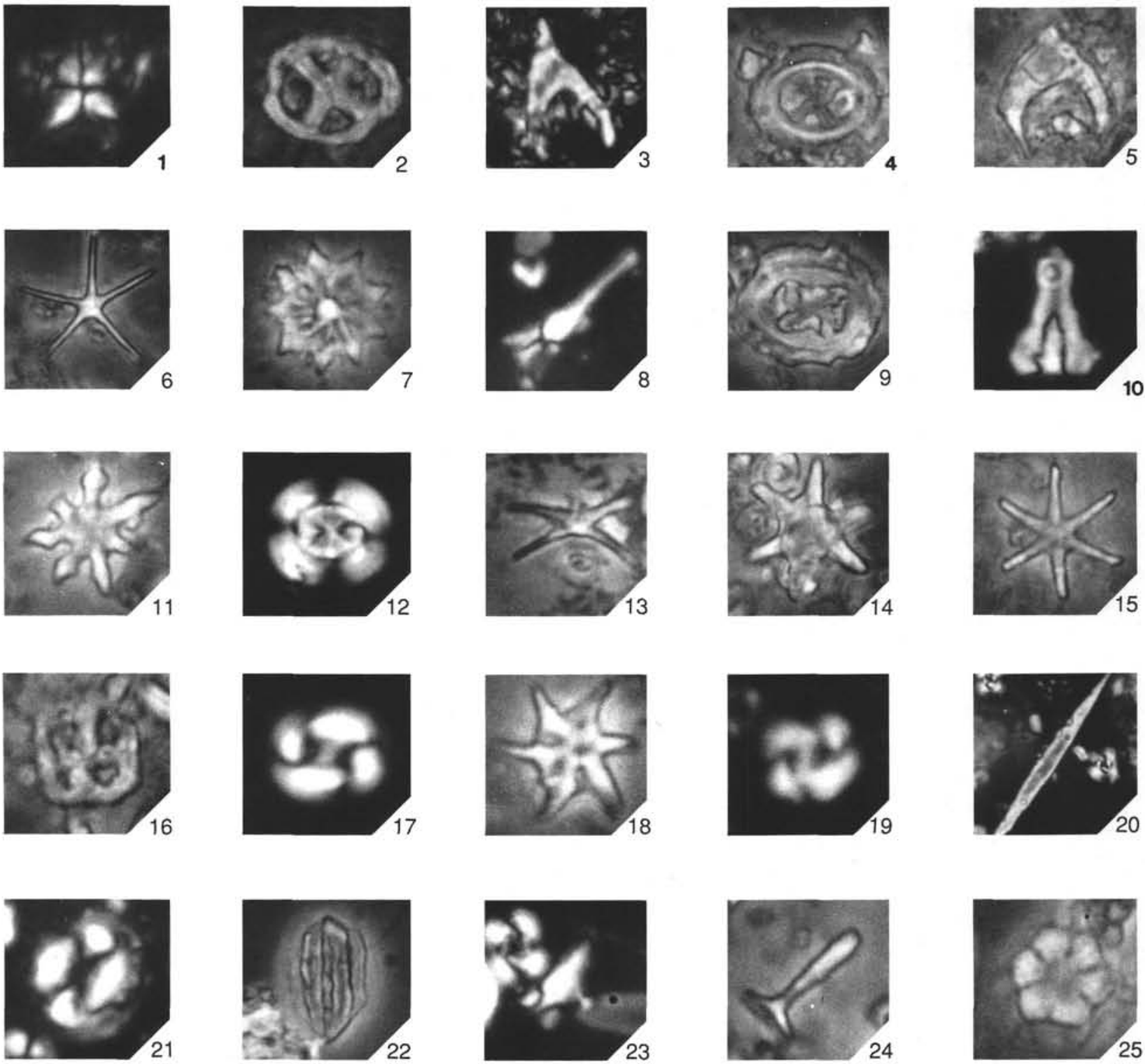

Plate 1. Cenozoic calcareous nannofossils. $\mathrm{XN}=$ cross-polarized light; $\mathrm{PC}=$ phase contrast. Magnifications approximate. 1 . Sphenolithus abies, XN, $\times 1500$. Sample 122-762B-9H-5, 100-101 cm. 2. Chiphragmalithus acanthodes, PC, $\times 1800$. Sample 122-762C-18X-1, 100-101 cm. 3. Ceratolithus acutus, XN, $\times 2000$. Sample 122-762B-1H-CC. 4. Chiasmolithus altus s.I., PC, $\times 1900$. Sample 122-762B-19H-1, 100-101 cm. 5. Amaurolithus amplificus, PC, $\times 2000$. Sample 122-762B-12H-CC. 6. Discoaster asymmetricus, PC, $\times 1600$. Sample 122-762B-7H-3, 100-101 cm. 7. Discoaster barbadiensis, PC, $\times 1600$. Sample 122-762C-7X-CC. 8. Sphenolithus belemnos, XN, $\times 2000$. Sample 122-762B-15H-6, 88-90 cm. 9. Chiasmolithus bidens, PC, $\times 1700$. Sample $122-762 \mathrm{C}-$ 27X-1, 99-100 cm. 10. Zygrahablithus bijugatus, XN, $\times 1600$, Sample 122-762C-2X-3, 100-101 cm. 11. Discoaster binodosus, PC, $\times 1800$, Sample 122-762C-22X-CC. 12. Dictyococcites bisectus, XN, $\times 1600$. Sample 122-762C-7X-CC. 13. Discoaster blackstockae, $\mathrm{PC}, \times 1200$. Sample 122-762B-12H-1, 125-127 cm. 14. Tribrachiatus bramlettei, PC, $\times 1800$. Sample $122-762 \mathrm{C}-27 \mathrm{X}-1,99-100 \mathrm{~cm} .15$. Discoaster brouweri, PC, $\times 1300$. Sample 122-762B-8H-1, 100-101 cm. 16. Chiphragmalithus calathus, PC, $\times 1800$. Sample 122-762C-22X-CC. 17. Dictyococcites callidus s.1., XN, $\times 1500$. Sample 122-762C-3X-3, 100-101 cm. 18. Catinaster calyculus, PC, $\times 2900$. Sample 122-762B-13H-3, 100-101 cm. 19. Gephyrocapsa caribbeanica, XN, $\times 2200$. Sample 122-762B-1H-1, $100-112 \mathrm{~cm} .20$. Triquetrorhabdulus carinatus, $\mathrm{XN}, \times 900$. Sample $122-762 \mathrm{C}-17 \mathrm{H}-1,100-102 \mathrm{~cm} .21$. Ericsonia cava, XN $\times 1400$. Sample $122-762 \mathrm{C}-$ $35 \mathrm{X}-2$ 100-101 cm. 22. Triquetrorhabdulus challengeri, PC, $\times 1000$. Sample 122-763A-17H-CC. 23. Sphenolithus ciperoensis, XN, $\times 2400$. Sample 122-762B-17H-3, 100-102 cm. 24. Rhabdosphaera claviger, PC, $\times 2000$. Sample 122-762B-1H-1, 100-112 cm. 25 . Catinaster coalitus, PC, $\times 2000$, Sample 122-762B-13H-CC. 

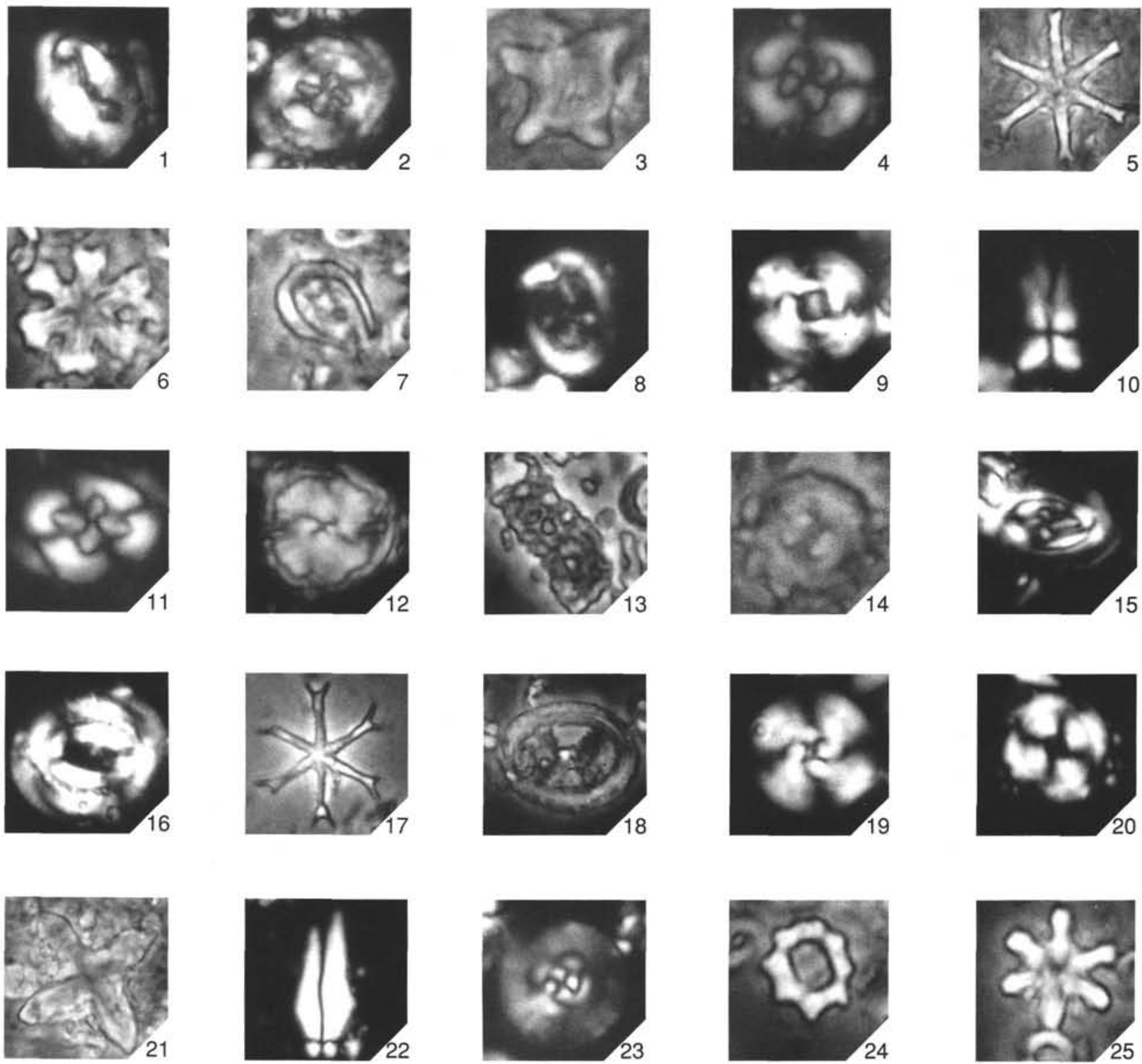

Plate 2. Cenozoic calcareous nannofossils. $\mathrm{XN}=$ cross-polarized light; $\mathrm{PC}=$ phase contrast. Magnifications approximate. 1. Helicosphaera compacta, XN, $\times 1600$. Sample $122-762$ C-7X-CC. 2. Chiasmolithus consuetus, XN, $\times 1200$. Sample 122-762C-29XCC. 3. Tribrachiatus contortus, $\mathrm{PC}, \times 1400$. Sample $122-762 \mathrm{C}-27 \mathrm{X}-3,99-100 \mathrm{~cm}$. 4. Chiasmolithus danicus, XN, $\times 2000$. Sample 122-762C-38X-5, 100-101 cm. 5. Discoaster decorus, PC, $\times 1400$. Sample 122-762B-8H-1, 100-101 cm. 6. Discoaster deflandrei, PC, $\times 1400$. Sample 122-762C-4X-CC. 7. Amaurolithus delicatus, PC, $\times 1800$. Sample 122-762B-12H-CC. 8. Campylosphaera dela, XN, $\times 1800$. Sample 122-762C-19X-1, 100-101 cm. 9. Reticulofenestra dictyoda, XN, $\times 1500$. Sample 122-762C-14X-3, $100-101 \mathrm{~cm} .10$. Sphenolithus dissimilus, XN, $\times 1500$. Sample 122-762B-16H-3, 100-101 cm. 11. Cruciplacolithus edwardsii, XN, $\times 1800$. Sample 122-762C-40X-CC. 12. Bomolithus elegans, XN, $\times 1800$. Sample 122-762C-34X-CC. 13. Clathrolithus ellipticus, PC, $\times 1000$. Sample 122-762C-22X-5, 100-102 cm. 14. Toweius eminens, PC, $\times 2200$. Sample $122-762 \mathrm{C}-30 \mathrm{X}-1,100-101 \mathrm{~cm}$. 15. Campylosphaera eodela, $\mathrm{XN}, \times 2400$. Sample 122-762C-27X-1, 99-100 cm. 16. Coccolithus eopelagicus, $\mathrm{XN}, \times 900$. Sample $122-762 \mathrm{C}-7 \mathrm{X}-\mathrm{CC}$. 17. Discoaster exilis, PC $\times 1250$. Sample 122-762B-13H-3 100-101 cm. 18. Chiasmolithus expansus, PC, $\times 1000$, Sample 122-762C-18X-5, 100-101 $\mathrm{cm}$. 19. Cyclicargolithus floridanus, $\mathrm{XN}, \times 1300$. Sample $122-762 \mathrm{C}-18 \mathrm{X}-5,100-101 \mathrm{~cm}$. 20. Ericsonia formosa, XN, $\times 1400$. Sample 122-762C-7X-CC. 21. Nannotetrina fulgens, PC, $\times 1450$. Sample 122-762C-16X-3, 99-100 cm. 22. Sphenolithus furcatolithoides, XN, $\times 2000$. Sample $122-762 \mathrm{C}-14 \mathrm{X}-5,100-101 \mathrm{~cm}$. 23. Toweius gammation, XN, $\times 1800$. Sample $122-762 \mathrm{C}-18 \mathrm{X}-5,100-101 \mathrm{~cm} .24$. Corannulus germanicus, PC, $\times 2100$. Sample 122-762B-18H-CC. 25. Discoaster germanicus, PC, $\times 1800$. Sample 122-762C-22X-5, $100-102 \mathrm{~cm}$. 

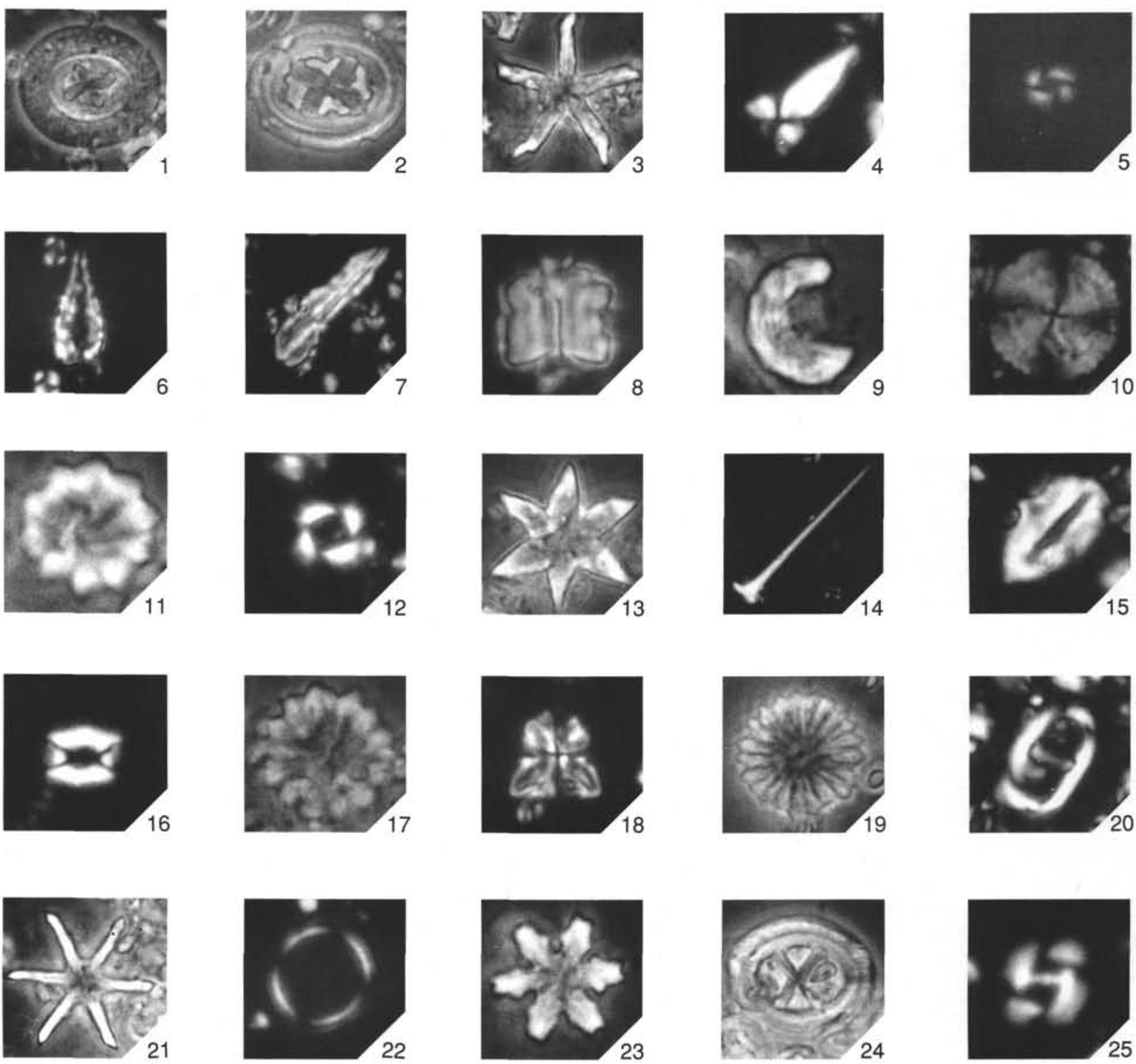

Plate 3. Cenozoic calcareous nannofossils. $\mathrm{XN}=$ cross-polarized light; $\mathrm{PC}=$ phase contrast. Magnifications approximate. 1. Chiasmolithus gigas, PC, $\times 1000$. Sample 122-762C-14X-CC. 2. Chiasmolithus grandis, PC, $\times 1100$. Sample 122-762C-11X-3, 99-100 $\mathrm{cm}$. 3. Discoaster hamatus, $\mathrm{PC}, \times 1100$. Sample $122-762 \mathrm{~B}-13 \mathrm{H}-3,100-101 \mathrm{~cm}$. 4. Sphenolithus heteromorphus, XN, $\times 1600$. Sample 122-762B-15H-1, 88-90 cm. 5. Emiliania huxleyi, XN, $\times 1900$. Sample 122-762B-1H-1, 110-112 cm. 6. Rhabdosphaera inflata, XN, $\times 1200$. Sample $122-762 C-17 \mathrm{X}-5,99-100 \mathrm{~cm}$. 7. Triquetrorhabdulus inversus, $\mathrm{XN}, \times 1100$. Sample $122-762 \mathrm{C}-14 \mathrm{X}-3,100-101 \mathrm{~cm} .8$. Fasciculithus involutus, XN, $\times 1100$. Sample $122-762 \mathrm{C}-29 \mathrm{X}-1,100-101 \mathrm{~cm}$. 9. Peritrachelina joidesa, PC, $\times 2100$. Sample 122-762B-18H-CC. 10. Heliolithus kleinpelli, XN, $\times 900$. Sample 122-762C-31X-1, 100-101 cm. 11. Discoasteroides kuepperi, PC, $\times 2100$. Sample $122-762$ C-18X-5, 100-101 cm. 12. Pseudoemiliania lacunosa, XN, $\times 2000$. Sample 122-762B-3H-1, 99-100 cm. 13. Discoaster lodoensis, PC, $\times 1800$. Sample 122-762C-18X-CC. 14. Rhabdosphaera longistylus, XN, $\times 850$. Sample 122-762B-5H-5, $100-101 \mathrm{~cm}$. 15. Triquetrorhabdulus milowii, $\mathrm{XN}, \times 1600$. Sample $122-762 \mathrm{~B}-16 \mathrm{H}-5,100-101 \mathrm{~cm}$. 16. Lanternithus minutus, $\mathrm{XN}$, $\times 1800$. Sample $122-762$ C-2X-3, 100-101 cm. 17. Discoaster mohleri, PC, $\times 1500$. Sample $122-762 C-30 X-1,100-101 \mathrm{~cm} .18$. Sphenolithus moriformis, XN, $\times 1400$. Sample 122-762C-17H-1, 100-102 cm. 19. Discoaster multiradiatus, PC, $\times 1300$. Sample 122-762C-27X-1, 99-100 cm. 20. Lophodolithus nascens, XN, $\times 1800$. Sample 122-762C-23X-CC. 21. Discoaster neohamatus, PC, $\times 1400$. Sample 122-762B-13H-3, 100-101 cm. 22. Coronocyclus nitescens, XN, $\times 1800$. Sample 122-762C-18X-5, $100-102 \mathrm{~cm} .23$. Discoaster nodifer, PC, $\times 1350$. Sample 122-762C-4X-CC. 24. Chiasmolithus oamaruensis, PC, $\times 1300$. Sample 122-762C-7X-CC. 25. Gephyrocapsa oceanica, XN, $\times 2200$. Sample $122-762 \mathrm{~B}-1 \mathrm{H}-1,110-112 \mathrm{~cm}$. 

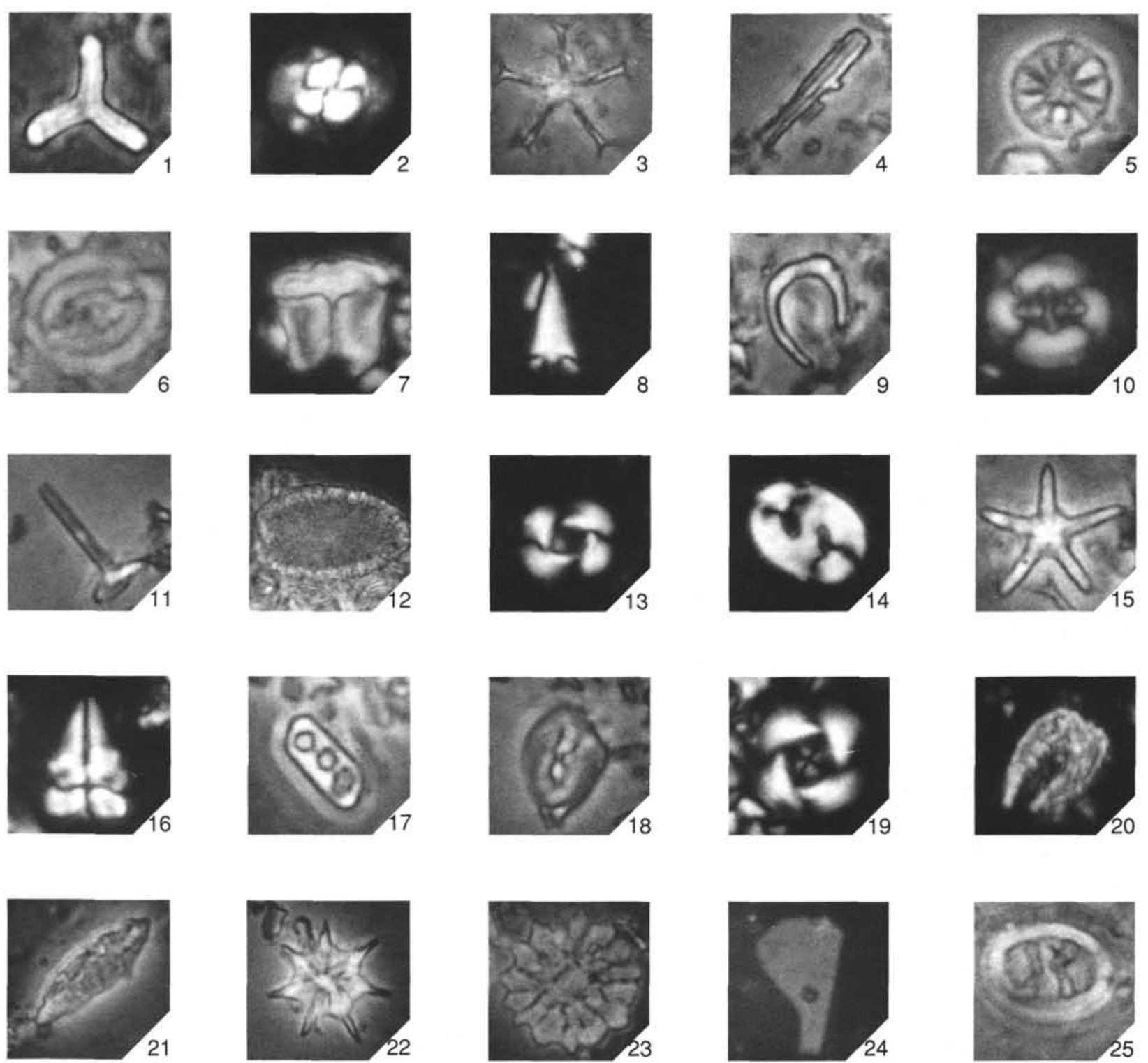

Plate 4. Cenozoic calcareous nannofossils. $\mathrm{XN}=$ cross-polarized light; $\mathrm{PC}=$ phase contrast. Magnifications approximate. 1. Tribrachiatus orthostylus, PC, $\times 1500$. Sample 122-762C-22X-CC. 2. Coccolithus pelagicus, XN, $\times 1600$. Sample 122-762C-3X-3, $100-101 \mathrm{~cm}$. 3. Discoaster pentaradiatus, PC, $\times 1800$. Sample $122-762 \mathrm{~B}-8 \mathrm{H}-1,100-101 \mathrm{~cm}$. 4. Rhabdosphaera perlongus, PC, $\times 1500$. Sample 122-762C-23X-3, 95-96 cm. 5. Hayaster perplexus, PC, $\times 1300$. Sample $122-762 \mathrm{~B}-16 \mathrm{H}-5,100-101 \mathrm{~cm}$. 6. Toweius pertusus, PC, $\times 2300$. Sample 122-762C-36X-1, 6-7 cm. 7. Fasciculithus pileatus, XN, $\times 1750$. Sample 122-762C-34X,-CC. 8. Sphenolithus predistentus, XN, $\times 2200$. Sample 122-762B-18H-CC. 9. Amaurolithus primus, PC, $\times 2000$. Sample 122-762B-12H-CC. 10. Cruciplacolithus primus, $\mathrm{XN}, \times 2000$. Sample $122-762 \mathrm{C}-42 \mathrm{X}-5,7-8 \mathrm{~cm}$. 11. Rhabdosphaera procera, PC, $\times 1900$. Sample $122-762 \mathrm{~B}-7 \mathrm{H}-3,100-101 \mathrm{~cm}$. 12. Thoracosphaera prolata, PC, $\times 800$. Sample $122-762 \mathrm{C}-13 \mathrm{X}-\mathrm{CC}$. 13. Reticulofenestra pseudoumbilica, XN, $\times 1800$. Sample 122-762B-13H-3, 100-101 cm. 14. Transversopontis pulcheroides, XN, $\times 1450$. Sample 122-762C-3X-3, 100-101 cm. 15. Discoaster quinqueramus, PC, $\times 1200$. Sample 122-762B-12H-CC. 16. Sphenolithus radians, XN, $\times 1500$. Sample 122-762C-20X-CC. 17. Isthmolithus recurvus, PC, $\times 1900$. Sample $122-762 C-4 X-1,100-101 \mathrm{~cm}$. 18. Helicosphaera reticulata, PC, $\times 1500$. Sample 122-762B-19H-1, 100-101 cm. 19. Reticulofenestra reticulata, XN, $\times 2000$. Sample 122-762C-7X-CC. 20. Ceratolithus rugosus, XN, $\times 1200$. Sample 122-762B-9H-5, 100-101 cm. 21. Triquetrorhabdulus rugosus, PC, $\times 1900$. Sample 122-762B-13H-3, 100-101 cm. 22. Discoaster saipanensis, PC, $\times 1400$. Sample 122-762C-7X-CC. 23. Discoaster salisburgensis, PC, $\times 1250$. Sample 122-762C-27X-3, 99-100 cm. 24. Bramletteius serraculoides, XN, $\times 1500$. Sample 122-762C-17H-1, 100-102 cm. 25. Chiasmolithus solitus, PC, $\times 1800$. Sample $122-762 \mathrm{C}-14 \mathrm{X}-3,100-101 \mathrm{~cm}$. 

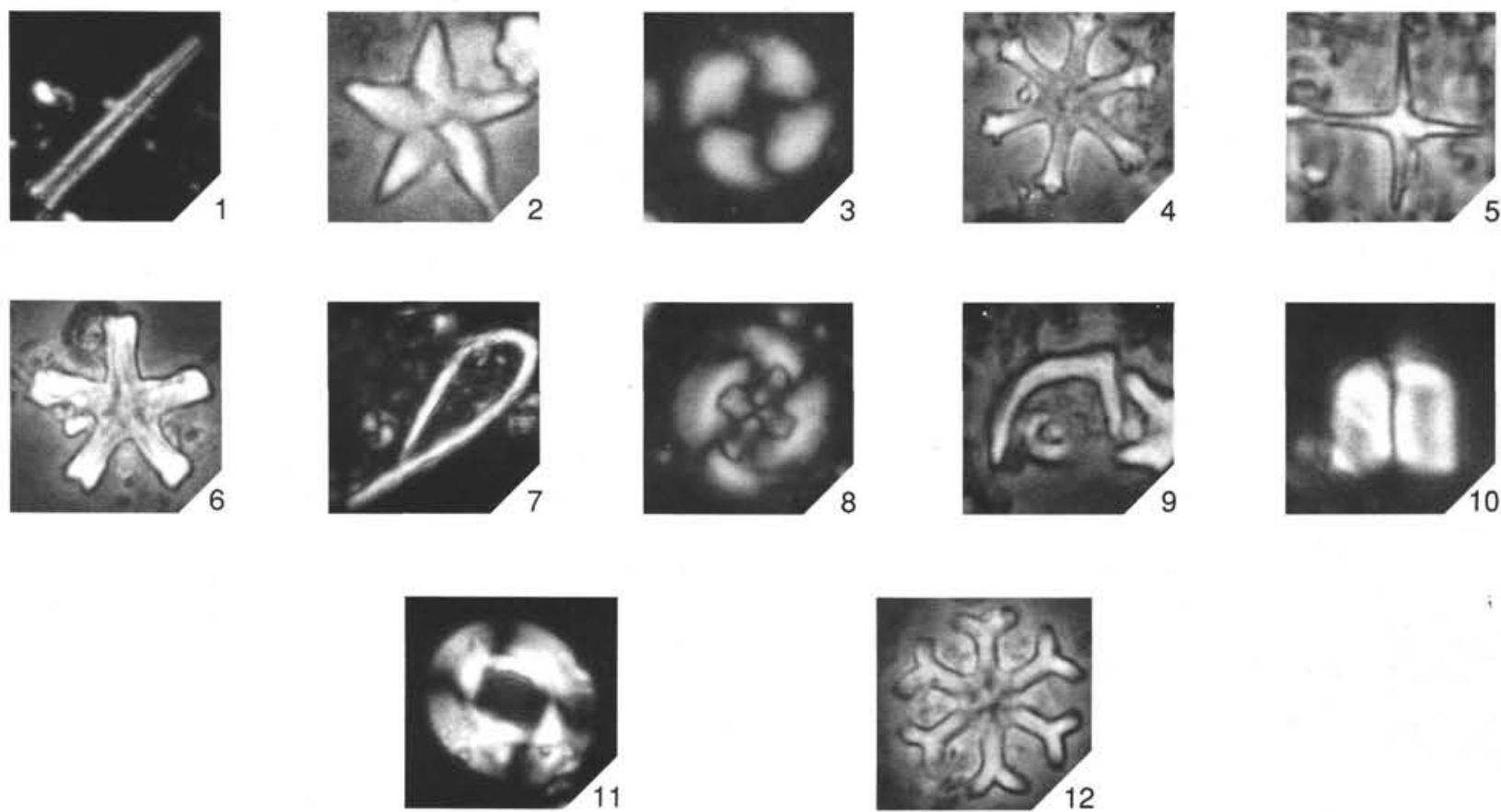

Plate 5. Cenozoic calcareous nannofossils. $\mathrm{XN}=$ cross-polarized light; $\mathrm{PC}=$ phase contrast. Magnifications approximate. 1 . Blackites spinosus, XN, $\times 1900$. Sample $122-762$ C-2X-3, 100-101 cm. 2. Discoaster sublodoensis, PC, $\times 1500$. Sample $122-762$ C$18 \mathrm{X}-1,100-101 \mathrm{~cm}$. 3. Ericsonia subpertusa, XN, $\times 1600$. Sample $122-762 \mathrm{C}-36 \mathrm{X}-1,6-7 \mathrm{~cm}$. 4. Discoaster surculus, PC, $\times 1100$. Sample 122-762B-11H-CC. 5. Discoaster tamalis, PC, $\times 1900$. Sample 122-762B-7H-3, 100-101 cm. 6. Discoaster tanii, PC, $\times 1650$. Sample 122-762C-7X-CC. 7. Ceratolithus telesmus, XN, $\times 850$. Sample 122-762B-1H-1, 110-112 cm. 8. Cruciplacolithus tenuis, XN, $\times 1500$. Sample 122-762C-39X-5, 79-81 cm. 9. Amaurolithus tricorniculatus, $\mathrm{PC}, \times 2000$. Sample $122-762 \mathrm{~B}-12 \mathrm{H}-1,125-127 \mathrm{~cm} .10$. Fasciculithus tympaniformis, XN, $\times 2000$. Sample $122-762 \mathrm{C}-31 \mathrm{X}-1,100-101 \mathrm{~cm} .11$. Reticulofenestra umbilica, XN, $\times 1400$. Sample 122-762C-7X-CC. 12. Discoaster variabilis, s.1., PC, $\times 1200$. Sample 122-762B-11H-CC. 